\title{
ECONOMICS
}

\section{REAL EXCHANGE RATE DETERMINATION AND THE CHINA PUZZLE}

\author{
by \\ Rod Tyers \\ Business School \\ University of Western Australia \\ and \\ Ying Zhang \\ Business School \\ University of Western Australia
}

DISCUSSION PAPER 14.19 


\title{
REAL EXCHANGE RATE DETERMINATION AND THE CHINA PUZZLE*
}

\author{
Rod TYERS \\ Business School \\ University of Western Australia, \\ Research School of Economics \\ Australian National University, and \\ Centre for Applied Macroeconomic Analysis (CAMA) \\ Crawford School of Government \\ Australian National University \\ Ying ZHANG \\ Business School \\ University of Western Australia,
}

DISCUSSION PAPER 14.19

Key words:

Real exchange rates, convergence, China, renminbi debate, imbalances, saving

JEL Codes:

C68,E27,E65,F31,F41,F43,O11

Author best contact details:

Rod Tyers

Winthrop Professor of Economics

UWA Business School

Crawley, WA 6009

Australia

rod.tyers@uwa.edu.au

\footnotetext{
* Funding for the research described in this paper is from Australian Research Council Discovery Grant No. DP0557885. Useful discussions on the topic with project partners Steve Dowrick, Heather Anderson and Jane Golley are acknowledged, along with subsequent discussions with Feng Lu and Iain Bain. Valued comments were also received at seminars at the China Center for Economic Research, Peking University and the Hong Kong Institute of Monetary Research.
} 


\begin{abstract}
While there is much controversy over exchange rates, particularly between the large, advanced economic regions, arguably more important real exchange rates receive comparatively little attention. Traditionally, these are seen to be influenced in the long run by forces that return economies to purchasing power parity (PPP) and by differences in productivity growth across sectors and across regions, as per the Balassa-Samuelson Hypothesis (BSH). Minor and realistic relaxations of the assumptions underlying the BSH greatly generalise the set of possible influences over real exchange rates, however. This paper surveys the literature on real exchange rate determination, as well as that addressing the puzzles over the trends in China's real exchange rate. While this was widely expected to appreciate against the advanced economies after China's first growth surge in the mid-1990s, it actually depreciated slightly until the early 2000s. Then, after 2005, its rate of appreciation was more rapid than expected. These puzzles are resolved by accounting for the effects of the trade liberalisations associated with WTO accession, China's excess saving and the tightening of rural labour markets.
\end{abstract}




\section{Introduction}

This paper offers a review of theoretical models and empirical analysis of real exchange rate movements. There has been much development in this literature during the past two decades and the key results to emerge have important implications for the real exchange rate of China against the other large, advanced economic regions on which global economic performance depends. The most durable of the elemental long run models of real exchange rate behaviour include purchasing power parity (PPP) and the Balassa-Samuelson hypothesis (BSH). ${ }^{1}$ The performance of these in practice is vulnerable to minor relaxations of underlying assumptions, though useful generalisations emerge for the medium to long runs. Short run behaviour depends closely on financial flows, however, and therefore on expectations over rates of return, making generalisation more difficult.

Nominal exchange rates are rates of exchange of different regions' monies, and so they are heavily dependent on monetary policies that are neutral in the long run. Real exchange rates, however, reflect the rates at which regions' production bundles are exchanged and hence reflect relative competitiveness and opportunities for profitable exchange. When firms in tradable industries lobby for policies that will depreciate the exchange rate, what they really want is to raise their output prices relative to their wage and other costs. In the short run this might be achieved by a monetary expansion that makes the home currency more abundant relative to foreign ones, so long as Keynesian nominal rigidities keep wage costs from rising with home currency output prices. In the medium to long run, however, such firms are only advantaged by true reductions in production cost relative to trading partners, and hence real depreciations.

If there is an across-the-board increase in productivity in all home sectors, relative home costs must fall and the real exchange rate therefore depreciates. Beyond this, since most firms carry intermediate costs, particularly in the form of non-traded infrastructural services, it is unambiguous that comparative productivity growth in services depreciates the real exchange rate. Under BSH assumptions, however, services are technically static while growth dynamics are driven in the tradable sectors. Then, a rise in tradable productivity relative to trading partners, and also relative to the home non-traded sector, gives rise to wage increases that drive up service prices, which in turn appreciate the real exchange rate. This gives rise to the idea that real exchange rates between developing and advanced economies

\footnotetext{
${ }^{1}$ See Balassa (1964) and Samuelson (1964).
} 
start out below PPP and converge toward it. It is this convergence that was expected during China's first growth surge but did not eventuate, giving rise to the China puzzle.

China maintained a de facto fixed exchange rate regime from 1994 until 2005, with the Renminbi (RMB) pegged to the US dollar within a narrow trading band. As official foreign reserves piled up the arguably low RMB came under the spotlight in political debates over its current account imbalance with the US. In scholarly circles, many supported this view. In his testimony to the US House of Representatives, Bergsten (2010) claimed that the RMB was undervalued by 25 per cent on a trade-weighted basis and by 40 per cent against the US dollar. Other estimates of the claimed undervaluation during this period range from 'small' to as large as 50 per cent. $^{2}$ A few commentators, including Cline (2005) and McKinnon (2006), argue that a RMB appreciation would not address the imbalances of concern to the U.S., the U.S. government started to exert pressure on China to appreciate its exchange rate. The debate has faded recently following the appreciation of the RMB by a third against the US\$ since 2005 and, most recently, since the release by the World Bank of the latest PPP estimates of GDP in April 2014, which suggest overvaluation of the RMB (McKinnon 2014, Kessler and Subramanian 2014).

Empirical evidence from studies by Lu (2006), Fogel (2006) and Tyers et al. (2008) suggests that China's tradable productivity growth has been double that of the US since the early 1990s (Gordon 2003, 2006) far out-pacing measured productivity in services. ${ }^{3}$ By the $\mathrm{BSH}$, this pattern, when combined with measured relative growth in Chinese real wages (Garnaut and Huang 2007), supports a real appreciation relative to the US. Yet the real wages of non-hukou workers were less formally recorded and Meng and Bai (2007), among others, suggest that these grew more slowly, if at all, at least until the mid-2000s. The BSH then posits that faster Chinese growth in both tradable productivity and real wages should cause a rise in relative non-traded services prices, which is also observed through the mid2000s (Lu 2006, Tyers et al. 2008). Thus, more specifically, the Chinese real exchange rate puzzle is that, all this evidence supporting the BSH notwithstanding, there was no significant real appreciation during the decade commencing in the mid-1990s.

The resolution of this puzzle depends most strongly on the relaxation of the assumption that the law of one price applies for all traded goods. This greatly broadens the set of

\footnotetext{
${ }^{2}$ See for example, Frankel (2004), Wang (2004), Goldstein (2004), Coudert and Couharde (2007), Tyers et al. (2008) and Cheung et al. (2007, 2010).

${ }^{3}$ Of course, productivity in services, and especially government services, is measured poorly, due to the presence of multi-product structures and the difficulty of measuring output volumes.
} 
determinants of the real exchange rate. The net effect of China's rapid economic growth on its real exchange rate is then seen to depend on the sources of that growth and the consequent pattern of endowment changes and sectoral distributions of productivity growth and tradability. Of considerable importance in the decade to the mid-2000s is the short run impact of China's widening current account surplus, which stems from its extraordinarily high total saving rate, and its WTO accession trade reforms.

Yet the puzzle relating to the failure to appreciate to 2004 was subsequently upstaged by a further puzzle surrounding the very rapid real appreciation since then. This strong reversal, by a third in nominal terms but more than twice that in real terms, occurred as China's growth surge began to slow, along with its excess savings, and the effects of WTO trade reforms began to wane. This change is further explored in this paper, which examines its determinants, noting mounting evidence not for a return to the dominance of the BSH but rather for a tightening labour market associated with an improved rural terms of trade and slowing labour force growth.

The next section offers a brief formalisation of the PPP concept while Section 3 formalises the BSH, both of which survey the associated literature. Generalisations are then offered in Section 4, also along with a review of the empirical evidence. Determinants of real exchange rates in the short run are considered via results from a simple short run macro model in Section 5. The paper then turns in Section 6 to the China puzzle and its resolution. Conclusions are offered in Section 7.

\section{Purchasing Power Parity}

Among the many theories applied to real exchange rate determination, PPP is the equivalent of the assertion that the real exchange rate converges on unity through time. Here the real exchange rate is defined as the rate at which the production bundle of goods from the home country can be exchanged, at current home and international prices, with the corresponding bundle abroad. This is the common currency ratio of the costs of these bundles, which is approximated by the ratio of their GDP prices. If the nominal exchange rate, $E$, is defined as the number of units of foreign exchange obtained for a unit of the domestic currency, $P$ and $P^{*}$ are price indices for home and foreign goods and services, then the real exchange rate, $e$, can be defined as: 


$$
e=\frac{P_{Y}}{\left(P_{Y}^{*} / E\right)}=E \frac{P_{Y}}{P_{Y}^{*}}
$$

Thus, 'absolute PPP’ suggests that the aggregated price level, when adjusted to a common currency, should be the same across countries. In other words, the real exchange rate should be equal to unity in the long run, as indicated in Table 1. 'Relative PPP' suggests a negative unit correlation between the nominal exchange rate depreciation and the difference between any two countries' inflation rates. In other words, if PPP holds, real exchange rates are stable through time. Observed real exchange rate movements therefore imply deviations from PPP.

If consumption baskets are the same and fully tradable across countries, international markets are frictionless and domestic markets are perfectly competitive, then PPP asserts a unit equilibrium exchange rate. Therefore, PPP is often seen as a baseline in judgements of exchange rate misalignment. ${ }^{4}$ Departures from it have therefore been noted since the collapse of the Bretton Woods system (Frankel 1981). A key source of these departures is the failure of the law of one price (LOP), an essential explanation for which is that services sectors have come to dominate industrial economies and these are primarily non-traded (Froot and Rogoff 1995). Possible other explanations include sticky prices (Obstfeld and Rogoff 1995), pricing-to-market (Krugman 1987) and trade cost (Engel and Rogers 1996). While a consensus has been reached that PPP does not hold continuously in the real world, 'most [economists] instinctively believe in some variant of purchasing power parity as an anchor for long-run real exchange rates’ (Rogoff 1996).

To test long-run PPP, econometricians concentrate on testing the stationarity of real exchange rates using time series and more recently panel data. Such tests are important because, first, they offer clues as to underlying reasons for real exchange rate movements. ${ }^{5}$ If a bilateral real exchange rate departs from PPP with persistence, then the shocks that drive departures from PPP must come from the real-side, such as technology shocks or factor endowment changes. If departures from PPP are less persistent, then it is possible that the initiating shocks are nominal, including innovations to monetary policy or increases in government spending that raise real demand temporarily. Second, if real exchange rates are

\footnotetext{
${ }^{4}$ As approximations to associated indices of misalignment, The Economist publishes the multi-currency prices of Macdonald's Big Mac and, more recently, the prices of Starbucks tall latte coffee.

${ }^{5}$ Stockman (1980) and Mussa (1986) introduced a long debate about the effects of nominal and real shocks. Stockman proposed that the volatility of real exchange rates comes from real shocks, while Mussa believed that nominal shocks also affect real exchange rates.
} 
found to follow random walks, the failure of PPP is implied and then PPP can no longer serve as an international parity condition (Taylor 1995). Such a level of failure would render defective a large range of macroeconomic models that embody the law of one price. Finally, where PPP is employed as the standard to identify real exchange rate misalignment, the observation of a unit root would have serious consequences for policy performance.

The empirical studies of PPP can be divided into three stages, according to the work of Frankel (1986), Rogoff (1996) and Taylor (2001). Reviews of the earliest studies (Froot and Rogoff 1996, Rogoff 1996), suggested that real exchange rates were non-stationary. Nevertheless, these results are widely recognized to depend on tests with weak power and short time series. Frankel (1986) points out that to reject the unit root in an AR(1) process with a half-life of 36 months at 5 per cent confidence level, 72 years of data are needed. The post Bretton Woods data used in the previous studies has therefore been insufficient to support such a conclusion. Subsequently, Lothian and Taylor (1996) used two centuries of pound-dollar (1791-1990) and pound-franc (1803-1990) data and they strongly reject the random walk hypothesis for the full sample and the pre-1945 period. Their estimates of the half-life of PPP departures are 5.7 years for pound-dollar and 3 years for pound-franc. Although the use of long time series data can solve the power problem, it covers a period dominated by the gold standard and fixed nominal exchange rates and it is widely expected that the real exchange rate is less volatile under pegged regimes. Another approach applies panel unit root tests. Frankel and Rose (1996) reject the unit root using a panel of 150 countries and the estimated half-life of decay is 4 years. Wu (1996) draws the same conclusion using monthly data for a panel of 15 OECD countries during 1974-1993 and his estimate of the half-life shrinks to 2.6 years, which is consistent with the results presented by Macdonald (1996).

Care is needed in the interpretation of the panel unit root test, as to whether the rejection of the unit root is due to the existence of just a few mean-reverting real exchange rates in the panel. Nonetheless, the predominating conclusion from the empirical studies is that real exchange rates deviate from PPP in the short run but they slowly return to their equilibrium levels. The estimates of the half-life of decay fall between 3 and 5 years. This gives rise to the PPP puzzle, proposed by Rogoff (1996): the reconciliation of the observed short-term volatility of real exchange rates and the estimated long half-lives of decay. Taylor 
et al. (2001) point out that the nonlinear mean-reverting process implied by the BSH might be a solution. ${ }^{6}$

Because they take nonlinearity in real exchange rate behaviour into account, some recent studies provide more supportive evidence of stationarity than earlier ones (Taylor and Taylor 2004). In particular, Kapetanios et al. (2003) propose a unit root testing procedure based on the exponential smooth transition autoregressive (ESTAR) model. Equipped with better power than the standard Dickey-Fuller test, they apply it to the stationarity of the bilateral real exchange rates of 11 OECD countries against the US dollar and are able to reject a unit root in many cases. Chortareas and Kapetanios (2004) test the Yen real exchange rate against other G7 and Asian currencies and find more supportive evidence of the trend stationarity of the Yen. ${ }^{7}$ To explain the variation amongst empirical findings, Zhou and Kutan (2011) use nonlinear unit root tests and recursive analysis and find great sensitivity of the stationarity test results to the choice of numeraire currencies, the sample period (in particular whether the period chosen covers regional or global financial crises), the inclusion of countries with different levels of economic integration, and the inclusion of a time trend. In the end, unit roots are rejected most frequently, consistent with economic theory, yet all the empirical studies find inescapable, significant and persistent deviations from PPP.

\section{The Balassa-Samuelson Hypothesis}

This is the popular explanation for persistence in the behaviour of real exchange rates. It depends on changes through time in productivity gaps between countries that create a comparatively smooth trend. Following Balassa (1964) and Samuelson (1964), the underlying theory separates industries as either fully tradable or non-tradable and the key determinant is the change through time in cross-country relative productivities in the tradable sectors. To formalise this, assume that the bilateral real exchange rate for a focus (home)

\footnotetext{
${ }^{6}$ Taylor, Peel and Sarno (2001) point out that the BSH effect implies that the real exchange rate does not converge to a constant mean but rather to a moving average. Taylor (2001) finds that if the actual mean reverting process is nonlinear, estimates of the half-life can be smaller. The half-life is less than 3 years for real exchange rate shocks below 5 per cent. It is even shorter with larger shocks. Taylor (2004) attributes this nonlinear adjustment to intervention by central banks.

${ }^{7}$ The robustness of this finding is then questioned by Kim and Moh (2012). They find strong non-stationarity by simply extending time series to 2008 while using the same test, and by applying a different test, inf-t test introduced by Park and Shintani (2005). On the contrary, Zhou (2012) supports the yen RER to be linear or nonlinear stationary around infrequent smooth temporary mean changes.
} 
country with a foreign trading partner $i$ can be approximated as the common currency ratio of the gross domestic product (GDP) prices (deflators) of the two countries: $P^{Y}\left(P^{N}, P^{T}\right)$ and $P_{i}^{Y}\left(P_{i}^{N}, P_{i}^{T}\right) / E_{i}$, where $P^{T}$ and $P^{N}$ are indices over all the focus country's non-traded and traded goods and services, respectively.

$$
e_{i}=\frac{P^{Y}\left(P^{N}, P^{T}\right)}{P_{i}^{Y}\left(P_{i}^{N}, P_{i}^{T}\right) / E_{i}}=E_{i} \frac{P^{Y}\left(P^{N}, P^{T}\right)}{P_{i}^{Y}\left(P_{i}^{N}, P_{i}^{T}\right)}
$$

Consider the case in which prices at home and abroad are measured relative to a common international numeraire $\left(E_{i}=1\right)$ and the share of non-traded products in GDP, $\theta_{i}$, is the same at home and abroad. Presume Cobb-Douglas production technology applies so that prices are appropriately aggregated using a Cobb-Douglas index and that tradable goods are internationally homogeneous and so subject to the law of one price. The latter implies that trade is costless and undistorted, so that $P^{T}=P_{i}^{T}$. Under these conditions, the real exchange rate becomes

$$
e_{i}^{R}=\frac{\left(P^{N}\right)^{\theta}\left(P^{T}\right)^{1-\theta}}{\left(P_{i}^{N}\right)^{\theta_{i}}\left(P_{i}^{T}\right)^{1-\theta_{i}}}=\left(\frac{P^{N}}{P_{i}^{N}}\right)^{\theta} .
$$

To illustrate the associated dependence on productivity, imagine that labour is the single fixed factor and that the rates of output per worker in the home traded and non-traded sectors are $A^{T}$ and $A^{N}$. In trading partner $i$, the corresponding rates are $A_{i}^{T}$ and $A_{i}^{N}$. The relationships between the wage rate and product prices in the traded and non-traded sectors follow from equating the wage in both sectors with the values of the marginal products of labour in each: $W=A^{T} P^{T}=A^{N} P^{N}, W_{i}=A_{i}^{T} P_{i}^{T}=A_{i}^{N} P_{i}^{N}$, from which it follows that the divergence in wage rates between trading partners depends only on their tradable productivities: $W / W_{i}=A^{T} / A_{i}^{T}$.

If the non-traded productivity level is the same in all trading partners $\left(A^{N}=A_{i}^{N} \forall i\right)$, we then have that

$$
\frac{P^{N}}{P_{i}^{N}}=\frac{A^{T}}{A_{i}^{T}}=\frac{W}{W_{i}} \text { and } e_{i}^{R}=\left(\frac{p^{N}}{p_{i}^{N}}\right)^{\theta}=\left(\frac{A^{T}}{A_{i}^{T}}\right)^{\theta}=\left(\frac{W}{W_{i}}\right)^{\theta} .
$$

When developing countries are growing rapidly relative to industrialised ones, productivity gains in their tradable sectors raise wages. This is because tradable prices are constrained by international trade and the law of one price, so improved productivity results 
in higher factor rewards. Labour market arbitrage then causes the price of non-traded services to rise, since that sector is assumed not to enjoy the productivity improvement. Then the relative aggregated price index rises in the growing country and a real appreciation is observed. Under the assumptions of the BSH, then, an economy that is growing faster than its trading partners also has 1) faster tradable productivity growth, $\hat{A}^{T}>\hat{A}_{i}^{T}$, 2) faster wage growth $\hat{W}>\hat{W}_{i}$, 3) relative service price inflation $\hat{p}^{N}>\hat{p}_{i}^{N}$, and 4) an appreciating real exchange rate $(\hat{e}>0)$. The hypothesis then implies that, if developing countries are poorer because their tradable labour productivity is lower, then their comparatively rapid growth should be associated with real appreciations against their richer trading partners. Support for the hypothesis requires that all four of its predictions be observed.

The BSH effect implies that the real exchange rate does not converge to a constant mean but to a trend that depends on the countries' levels of development. Ignoring this in empirical tests can therefore lead to overestimation of the half- life (Taylor et al. 2001, Chong et al. 2010). It also explains why richer countries usually exhibit higher GDP price levels than poorer countries. Even so, empirical evidence in support of the BSH is mixed. Lothian and Taylor (2008) find that the BSH effect is significant in the US-UK but not in the UKFrench real exchange rate over last two centuries. Dumrongrittikul (2012) studies annual data for 33 countries over the period 1970-2008, finding weak or contradictory results across the elements of the BSH and, in the end, offering only partial support. In a more supportive study, Berka and Devereux (2010) test a monthly/yearly micro dataset on price levels in 31 European countries over 13 years at both aggregated and disaggregated levels, and find that the variation in the real exchange rate can be largely explained by relative GDP per capita, both across countries and over time.

Some studies test explicitly for the role of the non-traded goods price in real exchange rate movements. Betts and Kehoe (2008) find that they are positively correlated using the quarterly bilateral real exchange rate for 1225 country pairs for 1980-2005. The relation holds for developed/developing country pairs and high inflation/low inflation country pairs. They also point out that the non-tradable price cannot fully explain real exchange rate volatility and they identify the US/EU rate as an anomaly. Of course, for countries similar in levels of development non-traded product prices are expected to be similar and other determinants of real exchange rates, such as departures from the product specific law of one price, are likely to be important. Overall, this literature is consistent with Engel (1999)'s 
finding that the price of traded goods explains most movements of real exchange rate of US in post Bretton Woods era.

It is important to bear in mind that the BSH effect evolves over time so that, as with studies in support of the PPP hypothesis, those using longer time series are more likely to find stronger evidence. Bergin et al. (2006) find that the BSH effect was insignificant in 1950s but became increasingly significant during the last several decades. Traditional BSH models assume the shares of tradable and non-tradable sectors, $\theta$, in the economy are exogenous. Ghironi and Melitz (2005) and Bergin and Glick (2009) challenge this, proposing endogenous tradability. Firms with more productivity gains are more likely to engage in trade and crowd out firms with lower gains, therefore widespread productivity improvements are likely to accompany increases in the proportion of products and services entering trade. This helps to explain why productivity growth is often observed in tradable sectors and thus, in this respect, it supports the BSH effect. Betts and Kehoe (2008) find stronger evidence of the BSH effect among countries with larger trade intensities.

Recent studies of industrialised and developing countries offer varying support for the BSH. Asea and Mendoza (1994) suggest there is little evidence of the BSH in data for 14 OECD countries between 1970-1985 they find that, while the productivity differential plays a significant role in explaining the corresponding long run price differential between traded and non-traded goods, it at best accounts for an insignificant proportion of observed changes in the real exchange rate. This notion is further explored in Chinn (1999) as he analyses the same 14 OECD countries over a longer time period, 1970-1997, while accounting for the price of oil due to its volatility over the period. Chinn finds some evidence for linkage between productivity bias and real appreciations, yet he comments that government spending is a more likely culprit in appreciating the real exchange rate, especially in the short run.

Halpern and Wyplosz (1997) examine transitional economies and observe real depreciations during the early transition period, followed by long term appreciations. Broeck and Slok (2006) show that the BSH effect is robust for 26 transition countries in the 1990s though it is notable that East Asia is not covered in their study. In East Asia, South Korea, Taiwan and other larger South-Asian countries do not show a continuous appreciating trend relative to the US and Europe. ${ }^{8}$ Recent work by Dumrongrittikul and Anderson (2013) is

\footnotetext{
${ }^{8}$ In East Asia, only Japan's experience supports the BSH. It had a steady real appreciation by about 1.5 per cent per year after 1880 (Taylor 2002).
} 
more supportive, while Dumrongrittikul et al. (2013) use an innovative global VAR approach to obtain results that also strongly support the links between tradable productivity and the real exchange rate. Some of the contradictory empirical results depend on the idiosyncratic experience of China. Despite comparatively rapid productivity gains in its tradable sector, it exhibited a contradictory real depreciation against the US dollar during 1996-2003, then appreciations thereafter. Research on this puzzle is reviewed in Section 6.

\section{Generalising the Balassa-Samuelson Hypothesis}

Failures of the BSH, particularly as they are represented in the East Asian transitional economies, stem from its core assumptions (Tyers et al. 2008). First, it is based on the LOP assumption, under which only non-tradable prices determine the real exchange rate.

However, the LOP is not observed in the real world due to the presence of sticky prices, trade costs, product differentiation and pricing-to-market (Engel and Rogers 1996). Therefore, factors that drive the country-specific tradable price levels $\left(P^{T}\right)$, as well as the relative price of non-tradable products $\left(P^{N} / P^{T}\right)$ both affect the real exchange rate.

Second, the BSH assumes that the productivity of non-traded sectors is the same across countries and unchanging through time. ${ }^{9}$ This condition is unlikely to be true, however, particularly for developed/developing country pairs. In some periods, developing countries may experience faster productivity growth in service industries as a result of microeconomic reforms that improve competitiveness in capital-intensive network services such as electricity, water, gas, telecommunications and transport. The resulting increases in nontradable output would drive down relative non-traded prices and depreciate real exchange rates. Thus, we might expect to observe real depreciations when productivity catch-ups in non-tradable sectors serve as the main source of economic growth.

Furthermore, the BSH ignores international capital flows, which are a dominant force in the global economy at present. For example, a decline in one country's investment risk premium initially causes a positive demand side effect. It redirects investment toward that economy, raising its financial capital inflow and hence raising investment and boosting aggregate demand. In the short run, this raises the demand for home relative to foreign goods and services and appreciates the real exchange rate. Combes et al. (2012) find supportive

\footnotetext{
${ }^{9}$ Personal services, such as haircuts, were seen as typical non-traded products and it is difficult to envisage productivity improvements in such industries.
} 
evidence for this behaviour by analysing real effective exchange rates for a sample of 42 developing countries over the period 1980-2006. They show that private portfolio investment flows, amongst other types of capital flows, have the largest short run impacts on real exchange rates. So a surge in investment inflows causes a short run real appreciation, while in the long run, a positive supply side adjustment occurs. The increased investment enlarges the capital stock in the destination country and so its capital services are more abundant and cheaper. This reduces that country's production costs relative to its trading partners and so depreciates its real exchange rate.

Finally, one of the key BSH assumptions is that labour arbitrage between the tradable and non-tradable sectors is perfect, equating the wages in these sectors. This assumption could also fail due to sticky wages and imperfect labour mobility. For instance, there are differences between the quality of labour arbitrage between agriculture and industry on the one hand and agriculture and services on the other (Chang and Tyers 2008). Industrial productivity growth may raise the real wage in that sector while an easier flow of new workers to services (such as construction) might restrain the rise in service wages relative to manufacturing wages. The effect of the industrial productivity growth in appreciating the real exchange rate would therefore be smaller since service costs would not be driven up by so much. Of course, services in general are comparatively skill-intensive and so the divergence could also be in the opposite direction. In any case, we expect that sectoral biases in labour arbitrage rates do affect the BSH effect on non-traded prices.

The most important of these generalisations of the BSH is likely to be failures of the LOP. If we loosen typical BSH assumptions to allow: $P^{T} \neq P_{i}^{T}, \theta \neq \theta_{i}$, then the real exchange rate is driven by three components, the relative price of home and foreign tradable goods, the relative price of home tradable and non-tradable goods and the relative price of foreign tradable and non-tradable goods:

$$
e_{i}=\frac{P^{T}}{P_{i}^{T}} \cdot\left[\left(\frac{P^{N}}{P^{T}}\right)^{\theta} /\left(\frac{P_{i}^{N}}{P_{i}^{T}}\right)^{\theta_{i}}\right] .
$$

Shocks that affect any of these relativities would change the real exchange rate trajectory. Hence, the generalisation of the BSH notably broadens the determinants of real exchange rate to include both supply side shocks such as factor endowment changes, structural reform that causes unbalanced industrial productivity growth; and demand side 
shocks such as to government spending, investment, trade policy, saving rates and consumer preferences.

\subsection{Supply and Demand Side Shocks}

A positive supply shock, such as a rise in industrial productivity in the home country, has two reinforcing effects in the short run. It has the BSH effect of raising wages and service prices and therefore the real exchange rate. But it also raises the rate of return to capital, leading to a capital inflow and hence a rise in domestic relative to foreign aggregate demand and therefore reinforcing the real appreciation. Supporting empirical evidence for this is found for the U.S. and Japan (Ito et al. 1999, Corsetti et al. 2008). In the long run, however, the higher productivity and the expanded capital stock reduce home costs and so act to moderate the initial real appreciation.

In the context of the 'new open economy macroeconomic models', which are extensions of the traditional sticky price Mundell-Fleming model in which capital is perfectly mobile, this real appreciation is associated with flexible product prices, sticky nominal wages and segmented global markets (Obstfeld and Rogoff 2000). In this context, where a productivity rise or a monetary expansion that raises employment applies across both tradable and non-tradable sectors, an increase in domestic output leads to a lower home GDP price and lower prices of exports relative to imports. Thus the home country's terms of trade deteriorate and the real exchange rate depreciates. Enders et al. (2011) analyse the effects of technology shocks on the U.S. real exchange rate over the period 1975-2005 and find consistent evidence in support of these predictions. The multi-country study by Dumrongrittikul et al. (2013) find similarly strong short run links to US monetary policy.

Apart from productivity gains, changes in factor endowments, such as labour supply contractions, also contribute to the long run trajectory of the real exchange rate. Life-Cycle theory argues that child-bearing increases consumption, as children consume more than they produce. A demographic contraction driven by a declining in birth rate reduces youth dependency and therefore consumption per capita. It therefore raises savings. Countries experiencing slowing population growth enjoy a period characterised by the 'demographic dividend', when there is lower dependency, higher per capita income and higher saving. Accordingly, other things equal, they have current account surpluses and real depreciations.

Both Japan and China have enjoyed 'demographic dividends' - in the post-war period for Japan and during the one child policy period (1982-2000) for China (Golley and Tyers 
2012). In the long run, however, as the 'Lewis turning point' approaches, the tightening labour supply and rising dependency ratio raises the real wage level, dampen economic growth, leading to a real appreciation. Aloy and Gente (2009) examine the effect of demographic change on the Yen-US Dollar real exchange rate in the period of 1960-2001 and find that Japan's aging population did contribute to the real appreciation since 1980s, due to a positive wealth effect. Yang et al. (2013) show that there is a clear rising trend in real wage rates in China since 2003, while we observe a substantial real appreciation at the same time (see Tyers and Zhang 2011). Rose et al. (2009) study a broad panel of 87 countries during 1975-2005 and confirm a strong link between fertility rates and real exchange rates.

According to the $\mathrm{BSH}$, the demand side does not influence non-tradable prices in a small open economy where labour and capital are free to move across sectors. Once we relax this assumption, short-run 'stickiness' in wages makes the demand-side a prominent determinant of relative prices. A positive home demand shock, for instance (say a trade reform or any switching of consumer preference from imports to domestic products) pushes up the relative prices of home products and this leads both to an appreciation of real exchange rate and an increase in output in the short run. ${ }^{10}$ In the long run, rising wages and factor mobility damp the effect, but the price level remains higher and the real exchange rate deviation persists for more than five years (Froot and Rogoff, 1991).

\section{Macroeconomic Behaviour and Short Run Real Exchange Rate Effects}

Since the end of the Bretton Woods era there has been freer international movement of private financial capital, which has necessitated the floating of exchange rates in the larger industrial economies and shifted the burden of short run stabilisation from fiscal to monetary policy. Since the GFC, however, monetary policy has been weakened by near-zero short term bond yields and there has been a resurgence of emphasis on government spending that will require significant fiscal consolidation in the coming decade. The emphasis in this section is on short run real exchange rate behaviour in response to the shocks considered previously but also to the monetary and fiscal policy shocks that are currently prominent.

\footnotetext{
${ }^{10}$ Trade reforms are the most obvious examples of demand switching but other government actions can have similar effects. Anecdotal cases include the launching by the Obama Administration of a series of investigations into the safety of Toyota vehicles during the subprime debt crisis. These tended to restore consumer confidence on American-made car brands, switching expenditure to home products. In China the investigation homesupplied powdered milk safety caused a substitution in favour of imported processed foods.
} 


\subsection{An Elemental Single Product Model of the Short Run}

The purpose here is to foster an intuitive understanding of the effects on the real exchange rate of short run shocks and responses. Two important determinants are ignored, namely relative price shocks (as between traded and non-traded goods) and mark-up changes in the presence of imperfect competition. These are considered in the sections 5.3 and 5.4. A conventional comparative static framework is employed based originally on the model of Mundell (1963) and Fleming (1962) but with a flexible price level. Imperfect financial capital mobility is assumed based on internationally differentiated financial assets (under which divergences occur across countries due to riskiness, financial regulatory frameworks and policy credibility). The short run equilibria considered fall short of uncovered interest parity in the Mundell-Fleming manner, so that financial outflows and inflows depend on bond yield differentials and exchange rate expectations.

As before the nominal exchange rate, $E$, is the value of the home currency in terms of foreign and the real exchange rate, $e$, is the rate at which representative bundles of home products and services can be traded for corresponding bundles abroad and hence the common currency the ratio of the home to the foreign GDP price, as per (Equation 1). The home and foreign regions supply differentiated single products, so the real exchange rate is just the ratio of their prices and it depends importantly on the supply side of the economy - in particular the cost of home relative to foreign production as discussed previously.

In the short run, the real exchange rate also depends on the level of excess demand for home relative to foreign goods and services and hence on the passage of net foreign demand via the balance of payments. Because the current account surplus is just the surplus of home saving over investment, the open economy financial capital market is central to the role of the demand side. It brings together home and domestic savers and investors, determining the yield on home assets. This market also determines net financial inflows on the capital and financial accounts, and hence the saving investment balance, along with the excess supply of foreign funds available to finance a current account deficit. To fully characterise the short run relationship it is therefore necessary to begin with the supply side and to model the real flows on the financial capital and foreign exchange markets subsequently.

\section{The supply side}

By convention in short run comparative statics, the length of run lies within the gestation period of new investment so the useful capital stock is fixed and the volume of 
output (real GDP) depends on employment: $Y=A L^{\alpha}$, where $\alpha$ is the labour share. The level of employment then sets the value of the marginal product of labour equal to the nominal wage, $W$, so that real GDP can be expressed in terms of the nominal wage and the price level, $P_{Y}$ :

$$
Y=A\left(\frac{\alpha A P_{Y}}{W}\right)^{\frac{\alpha}{1-\alpha}} .
$$

This supply side then enables us to express all volumes and expenditures in terms of representative bundles of home goods and services, or 'corn'. A full employment level of real GDP is achieved when $W$ is flexible, so that firms employ the profit-maximising number of workers. Real GDP is then fixed at this length of run, depending on the workforce and the available technology.

\section{The demand side}

First, to solve for equilibrium in the open economy financial capital market requires the characterisation of home saving and investment and net saving available from abroad. For this the first port of call is the national accounts. Define net factor income from abroad as $N$, and so real GNP is $Y+N$, and note that the current account of the balance of payments is then $C A=X-M+N$. The aggregate expenditure identity, $Y=C+I+G+X-M$ and the disposal identity, $Y_{N}=C+T+S$, can then be combined to yield:

$$
I-S_{D}=I-S-(T-G)=-[X-M+N]=-C A .
$$

This indicates that the excess of investment over total domestic saving, $S_{D}$, is equal to the current account deficit. We then combine the capital and financial accounts (hereafter the capital account) as $K A=-C A=S_{N F}-\Delta R$, where $S_{N F}$ is inflow due to acquisitions of home assets by foreigners net of foreign acquisitions by domestic residents and $R$ is official foreign reserves. All these are expressed in terms of home product bundles, or home 'corn'. Then

$$
I=S+(T-G)+S_{N F}-\Delta R
$$

This is the clearance condition for the open economy financial capital market, where $\Delta R$ is an exogenous monetary policy instrument. Since the endogenous components $I, S$ and $S_{N F}$ all depend on the equilibrating home real interest rate (home real long term bond yield) and the real exchange rate, $e$, formulations are required. We seek a tractable, elemental representation and so use linear relationships where possible. 


\section{Private saving, $S$ :}

Defining disposable income as $Y_{D}=Y_{N}-T$, a reduced form expression for consumption is

$$
C=a_{c}-a_{c r} r+a_{y} Y_{D}+a_{y f} Y_{D}^{e}
$$

where $Y_{D}^{e}$ is expected future disposable income, all the coefficients are positive and the marginal propensities, $a_{y}, a_{y f}<1$. This expression allows for consumption smoothing in response to shocks to current and expected future disposable income and for the empirically supported dominance of substitution over income effects in response to real interest rate changes. Saving is then: $S=\left(1-a_{y}\right) Y_{D}-a_{c}-a_{y f} Y_{D}^{e}+a_{c r} r$. Expanding disposable income for the case of a flat income tax at rate, $\tau$, we have $T=t+\tau Y_{N}=t+\tau(Y+N)$ and $Y_{D}=(Y+N)(1-\tau)-t$. Assume net factor income is constant, depending primarily on previous capital account flows. Then, if there is full employment and so $Y$ is fixed by labour supply and the nominal wage is endogenous in (6), then the level of real GNP, $Y_{N}$, is also constant, so that private saving depends on the home bond yield via the following supply relationship:

$$
S=\left[\left(1-a_{y}\right)(1-\tau) Y_{N}-\left(1-a_{y}\right) t-a_{c}-a_{y f} Y_{D}^{e}\right]+a_{c r} r
$$

Now we move to the other endogenous elements of the financial market equilibrium condition (8).

\section{Net foreign saving, $S_{N F}$ :}

Assume, in the Mundell-Fleming tradition, that private inflows represent the acquisition of home bonds and that the associated yields depend on imperfect arbitrage - the distance from uncovered interest parity. If the home yield is above the parity level inflows are encouraged, if below it, outflows. Adjustments most often move the market toward parity, though home inflows are also encouraged by expected real appreciations. Thus:

$$
S_{N F}=a_{f}+b_{f}\left(r-r^{*}+\hat{e}^{e}\right),
$$

where $\hat{e}^{e}$ is the expected proportional change in the real exchange rate expressed as positive for appreciations, $r$ and $r^{*}$ are the home and foreign real long term bond yields, and $b_{f}>0$. 


\section{Investment, I:}

Assuming the price of capital goods, $P_{K}$, inflates with the representative bundle of other goods and services embodied in the GDP price level, $P_{Y}$, the opportunity cost of funds tied up in new capital acquisitions is just $r P_{K}$ per unit. Net investment (the surplus over break-even, $I_{b}$ ) then depends on the extent to which the expected rate of return on installed capital net of depreciation,

$$
r_{c}^{e}=\frac{P_{Y} M P_{K}}{P_{K}}-\delta
$$

exceeds the real long term bond yield, $r$. Thus, we can write:

$$
I=\delta K+a_{I}\left(r_{c}^{e}-r\right)=I_{b}+a_{I}\left(r_{c}^{e}-r\right), \quad a_{I}>0
$$

This represents the final component of (8) so that it is now possible to solve for the bond yield.

\section{The real home interest rate (bond yield), $r$ :}

Substituting (10), (11) and (13) into (8) and solving for $r$ we have:

$$
r=\frac{\left[I_{b}+a_{c}-a_{f}-a_{c y} t\right]-\left[(1-\tau)\left(1-a_{c y}\right)-\tau\right] Y_{N}+G+a_{y f} Y_{D}^{e}+b_{f}\left(r^{*}-\hat{e}^{e}\right)+a_{I} r_{c}^{e}}{a_{I}+a_{c r}+b_{f}}
$$

With full employment and fixed $N, Y_{N}$ is constant, and, for a small open economy, the foreign bond yield, $r^{*}$ is also constant (unaffected by home fiscal or monetary policy). So, the slope of this with respect, for example, to government spending is

$$
\frac{d r}{d G}=\frac{1}{a_{I}+a_{c r}+b_{f}}\left[1+a_{c f} \frac{\partial Y_{D}^{e}}{\partial G}-b_{f} \frac{\partial \widehat{e}^{e}}{\partial G}+a_{I} \frac{\partial r_{c}^{e}}{\partial G}\right], \quad \frac{\partial Y_{D}^{e}}{\partial G} \leq 0, \quad \frac{\partial \widehat{e}^{e}}{\partial G} \geq 0, \quad \frac{\partial r_{c}^{e}}{\partial G} \geq 0
$$

If expectations are myopic this is unambiguously positive, yielding the traditional crowding out relationship. A positive relationship is reinforced if it is expected that spending will crowd out private investment, slow the rate of capital growth and leave the future rate of return on installed capital higher. But, if it is expected that more spending will reduce future disposable income (Ricardian equivalence) and appreciate the real exchange rate, then the result is ambiguous. Much therefore depends on the extent to which today's government spending causes the collective household to expect a greater tax burden in future, and hence to save more, or to expect an appreciated real exchange rate, and hence to rebalance toward 
home assets. The latter requires the unlikely event that the response of border flows to interest rate spreads and exchange rate expectations is so great ( $b_{f}$ is so large) that uncovered interest parity is near to applying in the short run. The weight of empirical evidence suggests the Ricardian equivalence and interest parity effects are weak enough that it remains positive.

Equation (14) also tells us about the effects on the home capital market of foreign shocks. If there is either a rise in the risk-adjusted foreign bond yield or an expected real depreciation, there is an unambiguous tightening of the home financial market, as measured by the home real long term interest rate. These negative external shocks both cause the equilibrium real long rate to rise in the short run. Shocks originating domestically might stem from expectations about future disposable income, government spending or the expected net rate of return on installed capital ('business confidence'). Raising expected future disposable income would reduce domestic private saving and also raise the bond yield. Any rise in the expected rate of return on installed capital would also tighten the home financial market in the short run.

\section{The foreign exchange market:}

Net inflows on the capital account offer a supply of foreign exchange that finances an excess of imports over exports, combined with net factor income flows $(N)$. Foreign exchange market equilibrium therefore implies the balance of payments, so that:

$$
C A+K A=[X-M+N]+S_{N F}=0 .
$$

We have assumed $N$ constant and we have behaviour for $S_{N F}$. To add behaviour for exports and imports consider each to be a demand function conventionally dependent on income and prices. Imports depend positively on home income, $Y_{N}$, and the home product GDP price, $P_{Y}$, and negatively on the after tariff foreign product price level in home currency, $\left(1+\tau_{M}\right) P_{Y}^{*} / E$, where $\tau_{M}$ is the average import tariff level. Yet the real exchange rate is just the common currency ratio of the home and foreign price levels (1), which enables us to express import demand as

$$
M=a_{M}-b_{M}\left(1+\tau_{M}\right) \frac{1}{e}+c_{M} Y_{N},
$$

where the inverse of the real exchange rate is just the relative price of the foreign goods and services bundle. Correspondingly, exports depend positively on this relative price and on foreign income: 


$$
X=a_{X}+b_{X} \frac{1}{e}+c_{X} Y_{N}^{*} .
$$

Substituting (17), (18) and (8) in (16) and solving for 1/e gives:

$$
\frac{1}{e}=\frac{c_{M} Y-c_{X} Y_{N}^{*}+a_{M}-a_{X}-a_{F}-b_{f}\left(r-r^{*}-\hat{e}^{e}\right)-N}{b_{X}+\left(1+\tau_{M}\right) b_{M}} .
$$

\subsection{Shocks in the Single Product Model of the Short Run}

Shocks affecting the real exchange rate in the short run therefore have many sources, including all the variables on the RHS of (19) as well as those determining the home bond yield (14). Consider some alternatives.

\section{Temporary supply side shocks}

Consider a shock to output:

$$
\begin{aligned}
& \frac{d}{d Y}\left(\frac{1}{e}\right)=\frac{1}{b_{X}+\left(1+\tau_{M}\right) b_{M}}\left[c_{M}+b_{f} \frac{\partial \hat{e}^{e}}{\partial Y}-b_{f} \frac{\partial r}{\partial Y}\right], \\
& \frac{\partial r}{\partial Y}=\frac{1}{\left[a_{I}+a_{c r}+b_{F}\right]}\left[-\left\{(1-\tau)\left(1-a_{c y}\right)-\tau\right\}-b_{F} \frac{\partial \hat{e}^{e}}{\partial Y}+a_{I} \frac{\partial r_{c}^{e}}{\partial Y}\right]
\end{aligned}
$$

Because the shock is temporary, the effects on expectations of future real exchange rates and rates of return on installed capital are negligible. This simplifies to:

$$
\frac{d}{d Y}\left(\frac{1}{e}\right)=\frac{1}{b_{X}+\left(1+\tau_{M}\right) b_{M}}\left[c_{M}+\frac{b_{F}\left[(1-\tau)\left(1-a_{c y}\right)-\tau\right]}{\left[a_{I}+a_{c r}+b_{F}\right]}\right]>0 \text {. }
$$

For reasonable values of the parameters, the numerator within the parentheses is positive, which ensures that there is a temporary appreciation of the real exchange rate.

\section{Expected permanent supply side shocks}

$$
\begin{aligned}
& \frac{d}{d Y}\left(\frac{1}{e}\right)=\frac{1}{b_{X}+\left(1+\tau_{M}\right) b_{M}}\left[c_{M}+b_{f} \frac{\partial \hat{e}^{e}}{\partial Y}-b_{f} \frac{\partial r}{\partial Y}\right], \\
& \frac{\partial r}{\partial Y}=\frac{1}{\left[a_{I}+a_{c r}+b_{F}\right]}\left[-\left\{(1-\tau)\left(1-a_{c y}\right)-\tau\right\}+a_{y f} \frac{\partial Y_{D}^{e}}{\partial Y}-b_{F} \frac{\partial \hat{e}^{e}}{\partial Y}+a_{I} \frac{\partial r_{c}^{e}}{\partial Y}\right]
\end{aligned}
$$

This yields 


$$
\frac{d}{d Y}\left(\frac{1}{e}\right)=\frac{\left[c_{M}+b_{f} \frac{\partial \hat{e}^{e}}{\partial Y}-b_{f} \frac{1}{\left[a_{I}+a_{c r}+b_{F}\right]}\left\{(1-\tau)\left(a_{y f}+a_{c y}-1\right)+\tau-b_{f} \frac{\partial \hat{e}^{e}}{\partial Y}+a_{I} \frac{\partial r_{c}^{e}}{\partial Y}\right\}\right]}{b_{X}+\left(1+\tau_{M}\right) b_{M}},
$$

which cannot readily be signed, even if there were clear priors on the effects of a permanent output boost on expectations over the exchange rate and the interest rate. An anticipated rise in present and future output raises the relative abundance of home products and might be considered to depreciate the real exchange rate, but stronger expected future income reduces saving and raises financial inflows, which appreciate it. Which force dominates is an empirical question.

\section{Foreign economic activity}

$$
\frac{\partial}{\partial Y_{N}^{*}}\left(\frac{1}{e}\right)=-\frac{c_{M}}{b_{X}+\left(1+\tau_{M}\right) b_{M}}<0
$$

Ignoring possible links between foreign income and foreign bond yields the effect of an output/income surge abroad is to cause a home real appreciation, driven by the increased relative abundance of foreign products.

\section{Foreign financial tightening}

$$
\begin{aligned}
\frac{d}{d r^{*}}\left(\frac{1}{e}\right) & =\frac{b_{f}}{b_{X}+\left(1+\tau_{M}\right) b_{M}}\left[1-\frac{\partial r}{\partial r^{*}}+\frac{\partial \hat{e}^{e}}{\partial r^{*}}\right], \\
& =\frac{b_{f}}{b_{X}+\left(1+\tau_{M}\right) b_{M}}\left[1-\frac{b_{f}}{\left(a_{I}+a_{c r}+b_{f}\right)}+\left(1+\frac{b_{f}}{\left(a_{I}+a_{c r}+b_{f}\right)}\right) \frac{\partial \hat{e}^{e}}{\partial r^{*}}\right]
\end{aligned}
$$

This is also formally ambiguous. If expectations over the real exchange rate are unaltered by a change in foreign yield then it is positive, suggesting that a tightening of financial markets abroad causes a financial outflow and hence a home real depreciation. Ironically, if such a real depreciation is anticipated it is less likely, suggesting that the initial level of the real exchange rate would have incorporated this expectation. ${ }^{11}$

\section{Expected real appreciation}

An expectation of a future appreciation causes a financial inflow and a rise in home bond prices, thus decreasing the home yield toward its uncovered interest parity level. From

\footnotetext{
${ }^{11}$ Note that, if there is a rise in the risk premium on home investment, the effect is the same as a rise in $r^{*}$, the opportunity cost of home investment. If this change has been unanticipated then the resulting outflow causes an unambiguous real depreciation.
} 
initial equilibrium, however, the short run change required in the real exchange rate is a depreciation, to accommodate the future rise.

$$
\frac{d}{d \hat{e}^{e}}\left(\frac{1}{e}\right)=\frac{b_{f}}{b_{X}+\left(1+\tau_{M}\right) b_{M}}\left[1-\frac{\partial r}{\partial \hat{e}^{e}}\right]=\frac{b_{f}}{b_{X}+\left(1+\tau_{M}\right) b_{M}}\left[1+\frac{b_{f}}{\left(a_{I}+a_{c r}+b_{f}\right)}\right]>0 .
$$

\section{Home government spending}

$$
\frac{d}{d G}\left(\frac{1}{e}\right)=-\frac{b_{f}}{b_{X}+\left(1+\tau_{M}\right) b_{M}}\left[\frac{\partial r}{\partial G}-\frac{\partial \hat{e}^{e}}{\partial G}\right] \text {. }
$$

Substituting (15) we have

$$
\frac{d}{d G}\left(\frac{1}{e}\right)=-\frac{b_{f}}{b_{X}+\left(1+\tau_{M}\right) b_{M}}\left[\frac{1+a_{c f} \frac{\partial Y_{D}^{e}}{\partial G}-b_{f} \frac{\partial \widehat{e}^{e}}{\partial G}+a_{I} \frac{\partial r_{c}^{e}}{\partial G}}{a_{I}+a_{c r}+b_{f}}-\frac{\partial \hat{e}^{e}}{\partial G}\right] .
$$

If expectations are insensitive to government spending this is unambiguously negative, confirming that a rise in government spending appreciates the real exchange rate by tightening the home financial market and attracting financial inflows. If expectations are consistent with (15), however, and a rise in spending leads to the anticipation of a decline in future disposable income and a rise in the real exchange rate, then the result is ambiguous. Much, therefore, depends on whether Ricardian equivalence is observed.

\section{Home expected rate of return on installed capital (business confidence)}

$$
\begin{aligned}
\frac{d}{d r_{c}^{e}}\left(\frac{1}{e}\right) & =-\frac{b_{f}}{b_{X}+\left(1+\tau_{M}\right) b_{M}}\left[\frac{\partial r}{\partial r_{c}^{e}}-\frac{\partial \hat{e}^{e}}{\partial r_{c}^{e}}\right] \\
\frac{d}{d r_{c}^{e}}\left(\frac{1}{e}\right) & =-\frac{b_{f}}{b_{X}+\left(1+\tau_{M}\right) b_{M}}\left[\frac{a_{I}+a_{y f} \frac{\partial Y_{D}^{e}}{\partial r_{c}^{e}}-b_{f} \frac{\partial \hat{e}^{e}}{\partial r_{c}^{e}}}{a_{I}+a_{c r}+b_{f}}-\frac{\partial \hat{e}^{e}}{\partial r_{c}^{e}}\right] .
\end{aligned}
$$

If expectations over future disposable income and the real exchange rate are insensitive to a surge in business confidence, then the result is an unambiguous real appreciation. This is reinforced if households are also more optimistic but offset if a real appreciation is anticipated, requiring the initial equilibrium real exchange rate to be lower. 


\section{Change in the home saving rate}

Consumption and savings behaviour is most simply shifted via the constant term in the consumption equation, $a_{c}$. An increase in this parameter signals a decline in saving, other things equal.

$$
\frac{d}{d a_{c}}\left(\frac{1}{e}\right)=-\frac{b_{f}}{\left(b_{X}+\left(1+\tau_{M}\right) b_{M}\right)\left(a_{I}+a_{c r}+b_{f}\right)}<0
$$

This confirms that a preference shift toward consumption causes an unambiguous appreciation of the real exchange rate, while a shift toward saving depreciates it.

\section{Change in tariff protection}

Assuming a change in the tariff protection rate does not alter expectations over future income or the real exchange rate we have:

$$
\frac{\partial}{\partial \tau_{M}}\left(\frac{1}{e}\right)=-\frac{b_{M}\left[c_{M} Y-c_{X} Y_{N}^{*}+a_{M}-a_{X}-a_{F}-b_{f}\left(r-r^{*}-\hat{e}^{e}\right)-N\right]}{\left(b_{X}+\left(1+\tau_{M}\right) b_{M}\right)^{2}}<0
$$

This confirms the result discussed earlier, that a rise in tariff protection appreciates the real exchange rate, while trade reforms depreciate it. It stems from demand switching. In the case of a tariff increase, demand is switched from foreign to home goods the relative price of which then rises.

\subsection{Monetary Policy}

In the model above a distinction is made between yields on short and long maturity assets, with yields on long instruments reflecting broader shocks to saving and investment while conventional monetary policy most directly influences short yields. ${ }^{12}$ The analysis centres on the long yield because the collective portfolio is dominated by long assets, both at home and abroad. Nominal long yields therefore represent the opportunity cost of holding money. In this framework, monetary expansions are created when central banks trade in short instruments, the markets for which are segmented between regions, serving domestic financial needs. Discretionary monetary expansions are only available to countries that float their exchange rates. In any given country, then, and under the assumptions maintained above, the direct effects of a discretionary monetary expansion are make the home currency

\footnotetext{
${ }^{12}$ Obviously, this assumption does not apply to the quantitative easing (UMP) observed in the large industrial economies at the time of writing.
} 
more abundant relative to home goods and relative to other currencies. It therefore causes both home inflation and a nominal depreciation. In the presence of nominal wage rigidity, this induces a rise in home employment and output.

The rise in output raises the abundance of home relative to foreign goods, and this depreciates the real exchange rate. Since home long maturity assets are differentiated from foreign ones and the rise in output and income increases home saving, the yield on home assets falls and global portfolios rebalance away from home bonds. This plays the reinforcing role by causing a shift in financial flows in the outward direction, reducing demand for home relative to foreign goods and hence enlarging the real depreciation. These effects are summarised in (20).

Early empirical tests of long-run PPP suggest that monetary policies are a major source of exchange rate volatility in the short run and medium run (Rogoff 1996). However, more recent studies show that the effect is not as large as once thought. In a Walrasian environment with no nominal rigidities, and hence when all markets clear and money is neutral, nominal shocks do not affect real variables. Even with nominal rigidities, the period of effectiveness is considered short. Monetary policy is always most directly linked to the nominal rather than the real exchange rate and nominal rigidities are required for real effects. Eichenbaum and Evans (1995) investigate the response of exchange rates to monetary policy shocks and find that money supply shocks do appear to play a role in real exchange rate variation, though they explain less than half. By contrast with the overshooting theory of Dornbush (1976), their results show 'delayed overshooting'. This is contradicted by the findings of Faust and Rogers (2000) and Bjoernland (2008), the latter analysing data for five small open countries, namely Australia, Canada, New Zealand, Sweden and the UK. He finds supportive evidence for overshooting and shows that, except for Canada, monetary policy changes contributed less than 15 per cent of real exchange rate variation.

\subsection{Fiscal Policy}

Many theoretical models suggest fiscal expansions widen the current account deficit and cause real appreciations. The single product model of 5.1 and 5.2 indicates that this is likely, though definitive short run results are shown to depend on expectations over future disposable income, and hence on the presence of Ricardian equivalence. The mechanism appears to be that reductions in home (government) saving tighten the home financial market, drawing in foreign investment (or reducing its outflow), shifting the current account toward 
deficit and temporarily raising home aggregate demand. This raises demand for home relative to foreign products. But foreign goods are elastic in supply to the small open economy whereas the output of home goods is constrained in the short run by fixed capital, technology and labour adjustment costs. Thus there is a rise in the relative price of home goods and hence a real appreciation. With Ricardian equivalence, home private saving rises and, combined with the crowding out effect on home investment, this at least moderates the need for financing from abroad and hence the effect on the current account.

\section{The Froot-Rogoff effect}

As many associated empirical studies suggest, the effects also depend on factors such as the initial government budget deficit, the country size and the completeness of international asset markets (Galstyan and Lane, 2009). Ricci et al. (2008) study a panel of 48 developing and developed countries in 1980-2004 and find that the effect of government consumption is highly significant. Froot and Rogoff (1991) find that increases in government consumption, which is largely biased towards non-tradables, tend to increase the relative price of non-tradables and thus gives rise to real appreciations. This conclusion is supported by the recent global econometric analysis by Dumrongrittikul and Anderson (2013). However, Kim and Roubini (2008) find the opposite when studying the effect of fiscal deficits on the current account and the real exchange rate in the US during the post Bretton Woods era. They find that, once business cycle effects are controlled for, an expansionary fiscal policy shock improves the current account and depreciates the real exchange rate. Finally, Galstyan and Lane (2009) extend the analysis to government investment and show that an increase in government investment may lead to real depreciation in the long run, if public investment disproportionately raises productivity in the non-tradable sector.

Thus, the early literature shows that government spending is an important explanatory variable in understanding real exchange movements (Froot and Rogoff 1996) yet the empirical studies do not speak with one voice. On one side we have Froot and Rogoff (1991), De Gregorio and Wolf (1994) and Galstayan and Lane (2009) all finding evidence that positive innovations in government spending cause real appreciations. On the other, the work by Kim and Roubini (2008) and the studies by Ravn et al. (2006, 2007), Monacelli and Perotti (2010) and Enders et al. (2011) all suggest that real depreciations appear to follow fiscal expansions. It must be said that these empirical studies are plagued by endogeneity and causality issues. Simple regressions of real exchange rates on government spending generally yield negative relationships, simply because government spending is most often 
countercyclical. But this does not mean that, other things equal, a rise in government spending must depreciate the real exchange rate. The challenge is always in the quality of controls for other determinants. In any case, according to the model of 5.2, negative relationships are possible, depending on expectation formation. There are other explanations, however. The economic stories behind these different links to the real exchange rate are summarised in the following.

Since the law of one price definitely does not apply to non-traded goods, their relative price influences the level of the real exchange rate. This is the Froot-Rogoff (1991) effect mentioned previously. Increased government spending raises the relative aggregate demand for non-traded goods. More government spending at home relative to abroad then raises the relative home price of home non-traded goods and hence the home GDP price relative to the foreign, thus appreciating the real exchange rate. The Froot-Rogoff effect emerges from their study of real exchange rate movements in Italy between 1986-1991. Productivity differentials were insignificant relative to government spending is a more significant determinant. This effect was subsequently confirmed by De Gregorio and Wolf (1994). Galstyan and Lane (2009) address the same issue in a combination of developing and developed countries. They also explore the effects of fiscal expansions on the relative price of non-traded goods and find that a rise in relative government spending by a per cent increases the relative non-traded goods price by nearly two per cent, which is consistent with the theory. In particular, they find that, while fiscal expansions increase output in both traded and non-traded goods, the non-traded sector 'disproportionately benefits.'

\section{Imperfect competition effects}

Service industries predominate in the non-traded sector and these are most often network-dependent (electricity, telecommunications, transport, water, gas). They therefore face high fixed costs and are most often either natural monopolies or oligopolies. So changes in these firms' mark-ups over their unit variable costs influence non-traded prices in general and, therefore, the real exchange rate. Oligopoly mark-ups are inversely linked with the elasticity of demand faced by these firms, implying that a shift in the direction of home tradable production away from comparatively elastic exports leads to higher mark-ups and real appreciations (Tyers 2014). The size of the "cone of non-tradability", which comprises all goods and services that are too costly to trade, depends on the magnitudes of market entry barriers. These are primarily natural barriers which limit the competition faced by these firms. Over the last few decades services sectors in many countries have been extensively 
privatised, yet their high fixed costs and other barriers to entry ensure that these industries remain highly oligopolistic. In most countries, the necessity has arisen to regulate these industries on price and operating effectiveness.

This regulation notwithstanding, information advantages over regulators ensure that these firms still have scope to choose their mark-ups over marginal cost. These mark-ups are inversely proportional to the elasticities of demand faced by oligopoly firms. When demand elasticities fall, mark-ups rise and a real appreciation is expected. In the case of homogeneous products, the optimal pricing rule for the standard oligopoly case with $n$ firms supplying a homogenous product is:

$$
\frac{P}{M C}=\frac{1}{1+\frac{\mu}{n \varepsilon}} \text {. }
$$

The optimal price is a function of marginal cost $(M C)$, a conjectural variations parameter $(\mu)$, and the price elasticity of demand in the home market $(\varepsilon<0)$. The conjectural variations parameter measures the influence of any one firm on the choice of output by other firms. Thus when $\mu=0$ and $P^{*}=M C$ the market is in perfect competition with no collusion. At the other extreme the cartel price is given by the conventional Lerner formula, where $\mu=n$. In between there is Cournot, or non-collusive, oligopoly, where the choice of output levels forms a Nash equilibrium and $\mu=1$. The price elasticity, $\varepsilon$, is determined by various sources of demand and their elasticities:

$$
\varepsilon=S_{F} \varepsilon_{F}+S_{I} \varepsilon_{I}+S_{V} \varepsilon_{V}+S_{G} \varepsilon_{G}+S_{X} \varepsilon_{X}, \quad \varepsilon_{X}>\varepsilon_{F}>\varepsilon_{V}>\varepsilon_{I}>\varepsilon_{G}
$$

Sources of demand are final (F), intermediate (I), investment (V), government (G) and export (X) with the sum of the demand shares, $S$, is unity (Tyers 2014). Export and final demand are the most elastic while 'just in time' production networking makes intermediate demand little more elastic than government demand (Harris and Cox 1984).

When fiscal expansions are undertaken the share of government and intermediate demand increases while that of export demand decreases. This is because total domestic saving declines and so must net exports. The economy becomes more inward-focussed as firms supplying intermediates domestically and at low elasticities do so to a greater extent than previously while exports decline, which causes average mark-ups to rise and the real exchange rate to appreciate. 


\section{Habit persistence combined with Imperfect Competition}

While most evidence supports the positive relationship between government spending and the real exchange rate suggested by the simple model of 5.2 and the Froot-Rogoff effect, some recent papers suggest an opposing force. This force stems from a combination of habit persistence ('deep habits') and imperfect competition, which results in a real depreciation as the relative price of non-traded goods declines when governments increase spending. Monacelli and Perotti (2006) and Ravn et al. (2006) both argue that the relative price reduction can be explained by two mechanisms. These mechanisms are the price-elasticity effect of deep habits and an inter-temporal effect.

The Price-elasticity effect of deep habits depends on fiscal expansions having expansionary effects on output and employment and thereby on consumption expenditure. The increased expenditure on home goods and services is discretionary than the old and therefore the demand associated with it is more elastic. The increased elasticity then induces firms to reduce their mark-ups, forcing downward pressure on the price of non-traded goods and hence the real exchange rate. This economic story is unconvincing, however, since fiscal expansions are most often countercyclical, designed to reduce declines in consumption expenditure in business cycle troughs rather than as a source of growth. If troughs cause consumption expenditure to fall into the 'essentials' range, fiscal smoothing is unlikely to cause net increases in the elasticity of demand for home goods and services. This argument is therefore unlikely to offset the tendency for non-traded prices to rise with increased government expenditure.

The Inter-temporal effect depends on a rise in government spending inducing 'an increase in the present value of future per-unit profits' which induces firms to reduce mark-ups at present. As firms are forward looking they are aware that current prices for goods will affect future demand via 'habit formation'. Thus, if they are able to increase sales at present through reduced prices it will lead to increased value to the firm in the future. Expecting that a fiscal expansion will raise future demand, they perceive that increases to the customer base at present, via price reductions, will ensure demand remains high in the future when prices rise again. Once higher consumption expenditure is 'habitual', firms can exploit this by eventually raising mark-ups. Thus, firms observe the fiscal expansion, anticipate accelerated growth in consumption demand and seek to use this to establish favourable habits in behaviour. 
The story is akin to predatory pricing. It is also questionable since fiscal expansions are countercyclical, occurring when consumption demand is low. There is therefore most often no bubble in consumption expenditure to exploit for the purpose of establishing 'deep habits'. Nonetheless, the price elasticity and inter-temporal effects offer an alternative economic story that could explain a negative link between government spending and the real exchange rate should it emerge. Indeed, work done recently by Moncalli and Perotti (2010), who (inappropriately) use a consumer price index (CPI) based real exchange rate, find evidence for the US, Australia, Canada and the UK that real depreciations follow fiscal expansions. ${ }^{13}$ Moreover, they also find evidence that the relative price of non-traded goods decreases. The source of our scepticism about these results is that, because fiscal policy is most often countercyclical, spending is high at times when real exchange rates are low. A simple OLS regression of one against the other therefore invariably yields a negative relationship. The power of the result, however, depends on the extent to which business cycle effects are controlled for.

\section{China's Real Exchange Rate Puzzle}

While the wider empirical evidence in support of the BSH is mixed, when price levels are compared through time and across large numbers of countries the pattern of real appreciation amongst the more rapidly growing countries is observed. ${ }^{14}$ For the case of China, we observe convincing evidence of faster tradable productivity growth (Table 2) and higher price inflation in the service sector ('tertiary' industry and construction) through the mid-2000s (Figure 1). Yet, as Figure 2 shows, no real appreciation was observed until after 2003. For a reflection of this in monthly data a real exchange rate is constructed from Chinese and US producer price indices in Figure 3, which shows the same real depreciating trend through the mid-2000s with a subsequent real appreciation in the lead-up to the GFC.

The scale of the real appreciation measured by the GDP price is significantly larger than that measured by the PPI. In particular, the former series climbs up steadily while the

\footnotetext{
${ }^{13}$ The CPI is an inappropriate deflator for the real exchange rate because it includes imported goods and thus sensitive to the nominal exchange rate. A real exchange rate should compare prices of a representative bundle of home goods and services with those of a corresponding bundle abroad.

${ }^{14}$ As discussed in Section 3, Cheung et al. (2007) and Bergin et al. (2006) show the trend across countries and through time well. Other studies with more mixed results include those by Engel (1999), Choudhri and Khan (2004), Miyajima (2005) and Dumrongrittikul (2012).
} 
latter levels off in the period of 2010-2012. This is due to the deviation of China's GDP price from its PPI. China's GDP price trend is driven by rising service prices and the rising share of the service sector, which is largely not incorporated in the manufacturing-focused PPI. Whichever way it is measured, however, the real depreciation through 2003 is a major departure from expectations grounded in the BSH which was noted initially by Tyers and Golley (2008) and subsequently examined in detail by Tyers et al. (2008). Clearly, to understand the path of China's real exchange rate a generalization of the BSH is required, and this means applying the results in Sections 4 and 5 to the Chinese case.

\subsection{Modeling Growth Shocks and China's Real Exchange Rate}

To capture the changes observed in China's real exchange rate, a numerical model is required that is global in scope and that incorporates the generalisations of the BSH discussed above. Recall that these included productivity growth in non-tradable as well as tradable sectors, departures from the law of one price for tradable goods, a more sophisticated representation of the labour market and an open capital account. With these generalisations, almost all shocks to the economy have implications for the real exchange rate. We draw on the modelling work of Tyers and Golley (2008) and Tyers et al. (2008), who construct a multi-region, multi-product dynamic simulation model of the world economy that subdivides the world into 14 regions, with the Chinese economy defined to include Taiwan and Hong Kong. ${ }^{15}$ Industries are aggregated into three sectors: food (agriculture, including processed foods), industry (mining and manufacturing) and services (including construction) - the latter being little traded in comparison with the other two. Failures of the law of one price are represented by product differentiation, so that consumers substitute imperfectly between products from different regions. As in other dynamic models of the global economy, the primary endogenous component of simulated economic growth is physical capital accumulation. Technical change is introduced in the form of exogenous productivity growth that is sector and factor specific, allowing the analysis of productivity performance that differs between tradable and non-tradable sectors.

Regional capital accounts are open and investors have adaptive expectations about real regional net rates of return on installed capital. In each region, the level of investment is determined by a comparison of expected net rates of return on domestic installed capital with

\footnotetext{
${ }^{15}$ The regions are Australia, North America (Canada, US, Mexico), Western Europe, Central Europe and the former Soviet Union, Japan, China, Indonesia, Other East and Southeast Asia, India, Other South Asia, Latin America, Sub-Saharan Africa, North Africa and the Middle East and the rest of the world.
} 
borrowing rates yielded by a global trust, to which each region's saving contributes, adjusted by calibrated region-specific interest premiums. Lagged adjustment processes ensure, however, that financial capital is not fully mobile internationally in the short term, but that the paths of domestic and global interest rates become parallel, separated only by exogenous premiums in the long term. In representing China, general financial reform is represented by a diminution of the interest premium and this causes an unambiguous rise in Chinese investment and hence a decrease in its current account surplus and an acceleration in its rate of physical capital accumulation.

To augment the model's characterisation of changes in labour supply and quality, it encompasses both demographic and economic change. It tracks populations in four age groups, two genders and two skill categories: a total of 16 population groups in each defined region. The skill subdivision is between production labour (unskilled) and professional labour (skilled). ${ }^{16}$ Each age-gender-skill group is represented as a homogeneous subpopulation with a group-specific birth and death rate, labour force participation rate, saving rate and rates of immigration and emigration. Because the non-traded sector is relatively intensive in skill, trends in skill composition prove to be particularly important. These depend on the rate at which each region's education and social development institutions transform unskilled (production-worker) families into skilled (professional-worker) families. Each year a particular proportion of the population in each production-worker age-gender group is transferred to professional status. The initial values of these proportions depend on the regions' levels of development, the associated capacities of their education systems and the relative sizes of their production and professional labour forces. Rates of transformation change through time in response to corresponding changes in real per capita income and the skilled wage premium. ${ }^{17}$

The focus is on shocks associated with China's growth. The most significant of these are productivity increases, skill transformation rate increases, interest premium decreases (increases in net financial inflows) and tariff decreases (increases in openness). In each case, a new simulation is run in which the determinant in question is shocked once and for all, as of

\footnotetext{
${ }^{16}$ The subdivision between production workers and professionals and para-professionals accords with the International Labour Organisation's occupation-based classification and is consistent with the labour division adopted in the GTAP Database. See Liu et al. (1998).

${ }^{17}$ China's skill share is projected to rise through time while that in its real exchange rate comparator, North America, remains static. The contrast is due to North America's higher initial skill share, its high rate of unskilled immigration and its higher fertility rate (Tyers and Bain 2006).
} 
2005. The elasticity of China's real exchange rate to each shock is then extracted, tracking the values through time to 2030. Changes in the bilateral real exchange rate are measured as in Equation 2, between China (including Taiwan and Hong Kong) and 'North America' (including Canada and Mexico), since this best parallels China's nominal exchange rate policy and the RMB valuation debate. The results are summarised in Figure 4. Consider each determinant in turn.

Sectoral total factor productivity: The elasticities shown represent the percentage departure of the projected real exchange rate for each percentage per annum increase in total factor productivity. The appreciating effects of tradable (industrial) productivity increases are consistent with the BSH and are, as expected, due to wage growth and relative service price inflation. They are bolstered in the short term by increased investment and hence greater net inflows on the capital account. In the long term, however, the enlargement of the industrial capital stock reduces costs and hence offsets the real exchange rate gains. Also, as expected from the dominance of non-traded sector prices in Equation 3, faster service productivity growth depreciates the real exchange rate-modestly in the early years but to a dominant extent in the long term, when it is reinforced by associated capital accumulation.

Skilling of the labour force: When the skill acquisition rate is increased in China, where the unskilled (or production) worker population is larger than its skilled (or professional) counterpart, the proportional boost to skilled workers is larger than the proportional loss of unskilled workers. The result is greater output and, other things being equal, a real depreciation. This tendency is enhanced by the fact that the services sector is comparatively skill intensive, so that the shock causes a relatively large boost to service output and hence a relatively large fall in the home service price (relative to North America). The result is a relatively large real depreciation in the long run. The elasticities in this case are percentage departures of the real exchange rate for each per cent of the production-worker (unskilled) population that is transformed each year. Defined this way, skill transformation places downward pressure on the real exchange rate of a magnitude similar to total factor productivity in services.

Financial influx: This is induced by a decline in China's interest premium. It raises investment and therefore increases aggregate demand and the real exchange rate. A positive demand-driven effect is therefore expected in the first instance. In the long term, however, when the effect of the investment on the capital stock is realised, the supply side dominates. More abundant and hence cheaper capital reduces production costs, yielding a real 
depreciation. The elasticity to investment premium decline (financial capital inflow) is large and positive in the short term, with the lag to the switch in sign measuring at least 15 years. ${ }^{18}$ Trade liberalisation: This switches demand away from home-produced goods and services towards imported varieties. For a single region, the supply of goods and services from the much larger foreign market is more elastic than that of home varieties, constrained as they are by local factor supplies and technology. The effect of the demand switch, then, is to reduce the relative prices of the home varieties and hence to depreciate the real exchange rate. The elasticity is constructed by dividing the percentage change in the real exchange rate by the percentage point change in the import penetration ratio (the ratio of the value of imports to the total value of domestic consumption). The shock on which it is based is a marginal reduction in all China's merchandise trade barriers. ${ }^{19}$ The elasticity, also shown in Figure 4, has the expected negative sign, and its magnitude grows through time. The growth in the magnitude of the elasticity through time is due to increased investment and hence capital growth. This occurs because the industrial sector, while it suffers from reduced protection, also benefits from lower tariffs on imported intermediate inputs. ${ }^{20}$

\subsection{Decomposing the Real Exchange Rate Changes of 1997-2006}

While it is clear that the BSH appreciating force has been in action in China, the generalisations allow consideration of countervailing forces and it is these that must have prevented any significant real appreciation between the mid-1990s and the mid-2000s. Strong depreciating forces that might have caused this include skill acquisition, which helps control wage costs in the skill-intensive services sector and therefore non-traded output prices, trade reforms and financial flows on the balance of payments. The simulation elasticities presented in Figure 4 support the conclusions of Section 5: financial flows dominate in the short to medium run. The significance of this for China is clear from Figure 5, which shows that the saving-investment gap (the current account surplus) expanded

\footnotetext{
${ }^{18}$ A corresponding shock to group saving rates was also introduced with similar results except that increased saving raises financial outflow, other things equal, and therefore depreciates the real exchange rate in the short run.

${ }^{19}$ The elasticity is insensitive to the scale of the liberalisation though not to the composition of China's protection. For the levels of protection embodied in the database for 1997, see Dimaranan and McDougall (2002).

${ }^{20}$ This effect is discussed in detail in Rees and Tyers (2008).
} 
substantially after the 1997 Asian financial crisis. This expansion in net outflows diverted domestic demand abroad and so placed downward pressure on China's real exchange rate. ${ }^{21}$

To see this, note that the equality of net inflows of payments on the capital account (net outflows on the current account) ${ }^{22}$ to the investment-saving gap follows from the standard aggregate expenditure and disposal identities. ${ }^{23}$ Defining net inflows as positive, the capital account surplus can be written as: $K A=S_{N F}-\Delta R=I-S_{D}$ where $I$ is investment, $S_{D}$ is total domestic saving, $S_{N F}$ (net foreign saving) is net private inflow on the financial account and $\Delta R$ is the annual addition to official foreign reserves. In the presence of capital controls, $S_{N F}$ is roughly equal to officially approved inward FDI. ${ }^{24}$ Both sides of the equation are negative in the case of China, indicating net outflows. Extraordinarily, even though investment then accounted for 45 per cent of China's GDP, more than half of its GDP was, and continues to be, saved.

While these outflows have surely been a depreciating force, the other two candidates may also have been important. The recent surge in overall income growth and urbanisation has seen an acceleration of skill acquisition and a boost to the service economy. At the same time, the lead-up to China's WTO accession saw a substantial reduction in trade distortions. To separate the effects of each of these forces on the real exchange rate note first the baseline model simulation over the period 1997-2006. This simulation incorporates all measured changes in sectoral productivity, skill acquisition and trade liberalisation. ${ }^{25}$ Finally, the trade reform shocks associated with the WTO accession are from Rees and Tyers (2008: Table 3). First, note that the real depreciation over this period is eight per cent, larger than observed in Figure 2 because of the country aggregations. Hong Kong and Taiwan experienced larger real depreciations against the US in this period and Canada and Mexico both experienced real

\footnotetext{
${ }^{21}$ Recent inter-temporal optimisation work finds China's growth pattern during the 1990s and 2000s, including its excess saving, to have been optimising. See Bacchetta et al. (2014).

${ }^{22}$ For our working definition of the "capital account”, KA, see note 10.

${ }^{23}$ The right hand side of this identity stems from the combination of aggregate expenditure on GDP, $Y=C+I$ $+G+X+M$; the fact that GNP is $Y_{N}=Y+N$, where $N$ is net factor income from abroad; the GNP disposal identity, $Y_{N}=C+T+S$, and the balance of payments, $B o P=0=K A+C A$, where the current account is $C A=$ $X-M+N$.

${ }^{24}$ China's capital controls have been leaky but, as Ma and McCauley (2007) find, remain very effective.

${ }^{25}$ The skill acquisition rates are calibrated using the model from wage and sectoral employment data, as described in Tyers and Bain (2006).
} 
appreciations against the US. By simulating each shock separately, the model is used to construct the decomposition summarised in Table 3.

Higher Chinese productivity growth is seen to have offered the expected BSH appreciating force. Net financial outflows on China's balance of payments and inflows on the North American balance of payments both tend to depreciate the Chinese real exchange rate. Similarly, skill acquisition (which reduces the cost of supplying mainly skill-intensive services) and trade reform offer the expected depreciating forces. In combination, the current account imbalances in both China and North America contribute a real depreciation of more than five per cent. Surprisingly significant, however, is the depreciating effect of WTO accession trade reforms, which contribute more than four per cent to the overall real depreciation. In the end, the current account imbalances prove to be, in combination, the most important depreciating forces to the mid-2000s.

\subsection{The Real Appreciation Since 2004}

The exchange rate reforms launched by the Chinese authorities in July 2005 were intended to at least demonstrate a departure from the de facto fixed US dollar peg, nominally allowing the currency to fluctuate by up to 0.3 per cent each day. The appreciation accelerated in 2007 and the net nominal appreciation amounted to around 20 per cent by July 2008, after which the global financial crisis induced the Chinese government to return to the de facto US dollar peg. This round of revaluation was accompanied by significant domestic inflation, implying a substantially larger appreciation of the underlying real exchange rate after 2004 (Figure 2), amounting to at least 60 per cent. As is evident from Figure 2, the difference between the bilateral nominal and real appreciations was associated with faster growth of China's GDP price than that of the United States. While this change in the path of China's real exchange rate is not subjected to a detailed decomposition, sufficient evidence does exist to enable us to discuss some alternative hypotheses.

Decreasing current account surplus: After a rapid increase in early 1990s, household saving rates fluctuated between 20 and 25 per cent during 1997-2006 (Tyers et al. 2013). The initial surge in household saving had been associated with the 1990s round of privatisation and restructuring, which increased household funding responsibilities for health, education and retirement expenses. In more recent years the government has embarked on national schemes for health and retirement insurance, including the extension of medical pension insurance to 
cover rural areas and the establishment of urban subsistence security systems. ${ }^{26}$ These help to reduce precautionary saving and hence to stabilise household saving rates. At the same time, there has been a surge in government spending as a response to the global financial crisis after 2007. This reduced the government's contribution to national saving. As shown in the Figure 5, the Chinese current account surplus peaked in 2007 and contracted afterwards. The prior period of real depreciation had been associated with the expansion of this surplus and hence the diversion of increasing shares of Chinese income into expenditures abroad. The cessation of this trend militates against further real appreciation.

Rising relative wage costs: The sectoral price indices of Figure 1 show no rise in the prices of services (the 'tertiary' and construction sectors) relative to the tradable goods sectors during 2003-2007. This suggests that the appreciation in that period is not due to the BSH force (relatively high productivity growth in China's tradable sectors) but, after the GFC, the service sector prices catch up again. Indeed, the striking change is in the price index for primary products, indicating a substantial improvement in the agricultural terms of trade. While this is due in part to higher prices of import competing commodities, we have already seen that there have been a number of favourable changes to policies affecting agriculture and the rural sector generally. These changes would have raised the marginal product of rural labour and therefore the incentive required for rural workers to migrate to Eastern cities.

Our application of the Zivot-Andrews test for a structural break to Chinese real wage data suggests a change in real wage growth for the agricultural and construction sectors in 2005- 2006, as indicated in Figure 6. The labour forces in these sectors are mainly unskilled and the rural labour market is the source of most non-hukou workers in construction, other services and manufacturing. The official agricultural and construction real wage both grew at 6.33 per cent per year in the period 1994-2004 and at 11.1, 10.1 per cent per year respectively in the period 2005-2012. ${ }^{27}$ In their study of the real wages of unskilled factory workers in Guangdong, Meng and Bai (2007) use payroll data to ensure the inclusion of non-hukou workers. They show a much smaller annual growth rate of between 0.5 and 1.5 per cent per year up to 2004, controlling for education and firm tenure. The take-off in rural wages after that time suggests, however, that real non-hukou rates have increased since, and this is to be

\footnotetext{
${ }^{26}$ See Chamon and Prasad (2008), Wen (2008).

${ }^{27}$ The growth rates were obtained from a robust OLS regression of the log of the nominal wage deflated by the CPI against time. The standard errors on the growth rate coefficients in both regressions are very small, suggesting the growth rates are significantly different.
} 
expected from the improvements in net returns from agricultural activity. Increasingly, it appears likely that potential 'floating workers’ are choosing to continue their rural employment.

Anecdotal indications of tightening labour markets have been abundant, including increased labour unrest suggesting improved labour market power in manufacturing provinces. ${ }^{28}$ What is in evidence is a slowing of urban labour supply growth, which drives up the cost of both tradable and non-tradable goods relative to China's trading partners, and hence causes the real exchange rate to appreciate. While this seems to be associated with agricultural incentives in the short term, along with improvements in infrastructure that have boosted local services sectors, in the long term the prospect can only be for a continuation. This is because demographic change already long in train will see China's total labour force begin to decline during the next decade (Cai and Wang 2006, Golley and Tyers 2006). In short, this change may be heralding the end of the era of the Dooley et al. (2003) 'revived Bretton Woods trade account' regions generating export growth on the back of surplus rural labour, at least so far as China is concerned (Feenstra and Hong 2007).

Increasing oligopoly rents: Lu et al. (2008) point out that Chinese state-owned enterprises (SOEs) still dominate industries such as metals, motor vehicles, aircraft, transport, telecommunication, finance and insurance and that they became extremely profitable during the growth surge of the early 2000s. Tyers (2014) attributes these profits to oligopolistic behaviour and sees the associated rents as having expanded with the post-accession growth surge, financing the huge corporate savings of the period. The effect of these rents on China's real exchange rate has two channels. First, higher mark-ups in largely non-traded industries raise prices and hence cause appreciation. Second, the rents gained by SOEs comprise a primary part of corporate saving, which has tended to divert Chinese expenditure abroad and thus depreciate the real exchange rate. As Tyers shows, the latter effect was dominant to 2005. The more recent decline in the corporate saving rate (Bayoumi et al. 2009) may have shifted this balance toward the appreciating effect of the mark-ups.

Slowing-down of trade reform: China's 2001 WTO accession saw a wide range of tariff cuts and market-opening policy changes. Since then trade reform has slowed. ${ }^{29}$ As discussed

\footnotetext{
${ }^{28}$ Strikes at key joint venture plants and other activism led to substantial increases in manufacturing wages in 2009 in engine room provinces of Guangdong and Zhejiang (Gardner 2010).

${ }^{29}$ According to the WTO’s Trade Policy Review (2008), the tariff is still one of China's main trade policy instruments. The overall average applied MFN tariff was $9.7 \%$ in 2007, the same as in 2005. The average
} 
previously, trade liberalisations depreciate the real exchange rate and so this slow-down might be seen as at least relaxing depreciating pressure. Yet trade reforms are never Pareto improving without compensation. The sector bearing the most negative effects from the WTO accession has been agriculture, the stagnation of which in the early years after the WTO accession probably contributed to the substantial rural-urban migration of the period (Chang and Tyers 2008, Rees and Tyers 2008). Thereafter, a major concern of the central government has been the welfare of farmers and other rural dwellers. Unlike the corresponding experiences of Japan, Korea and Taiwan during their growth surges, because of the WTO commitment, China has not been able to address the rural-urban divide using trade protection (Anderson and Hayami, 1986, Anderson, 2009, Duncan et al. 2008).

A consequence has been a trend from negative assistance to agriculture in the early reform period to positive and significant protection today, channelled via domestic marketing, transport, storage and other budgetary assistance, allowed under WTO rules for developing countries. ${ }^{30}$ Beyond agriculture, a number of trade-biased policies have emerged that cut against the spirit of the pre-accession reforms. Since 2005, the value-added tax (VAT) rebate for exporting firms has been re-raised nine times up to 17\%, covering approximately 3800 export products, including textile, clothing, toys, machinery, electric appliances, medicines, communication devices and steel. ${ }^{31}$ Such export encouraging policies divert home supplies abroad, raising the relative prices of domestic goods and hence appreciating the real exchange rate.

\section{Conclusions}

Widely accepted behavioural theories concerning real exchange rate behaviour are restricted to long run effects and, most prominently, to the BSH. It indicates that real appreciations stem from comparative productivity growth in home tradable industries. But the BSH depends on many strong assumptions. When these are relaxed, most economic shocks are

applied MFN tariff rates for agricultural and non-agricultural products were $15.3 \%$ and $8.8 \%$, respectively, also the same as in 2005.

${ }^{30}$ Huang et al. (2009: Table 5) show the trend in assistance to agriculture clearly. More recently, the speech by Wen (2010) indicates the central government plans to raise the agricultural subsidy to 133 billion Yuan in 2010. The same speech indicates that agricultural tax reductions were carried out in Anhui province in 2000 and were then extended to 30 provinces in 2003. By 2005, agricultural production taxes were completely cancelled in 28 provinces. Farmers' benefits were estimated at 133.5 billion Yuan per year.

${ }^{31}$ See Ministry of Commerce of the People's Republic of China (2009). 
seen to affect real exchange rate levels. In the long run, beyond tradable productivity differentials, these include international differences in services (non-traded) productivity, changes in factor endowments or oligopoly behaviour and the demand switching effects of shocks to saving behaviour, trade policy or home product preferences.

In the short run, cross-border financial flows are the critical determinants of real exchange rates since inflows deduct from aggregate demand in the country of origin and add to it at home, raising home relative to foreign product prices. The Mundell-Fleming view of these cross-border flows has them driven by yield differentials that stem from inter-regional differentiation of financial products by quality (riskiness) and technical characteristics. Financial arbitrage is therefore incomplete and uncovered interest parity is not observed. Nonetheless, expectations over exchange rates and other economic variables play crucial roles in the short run.

Relative to the US, Chinese productivity has grown faster in the tradable than in the non-tradable sectors, real wages have also growth faster and there has been relative service price inflation. The flat trajectory of China's real exchange rate between 1990 and 2004 is therefore a contradiction of the $\mathrm{BSH}$, the resolution of which requires generalisation to incorporate failures of the law of one price for tradable goods, open financial capital markets and a more sophisticated representation of the labour market. This opens the way for depreciating forces that have been offsetting the $\mathrm{BSH}$, including net financial outflows on the balance of payments associated with China's excess saving along with trade and other microeconomic reforms.

Decomposition of the flat trajectory of the real exchange rate over 1997-2004 reveals that the BSH is most strongly offset by the excess saving and the associated expansion of net outflows on its capital account, along with a significant additional contribution from WTO accession trade reforms. China's real exchange rate began appreciating in the mid-2000s when the national saving rate stabilised and trade reforms petered out. An examination of the trends in relative product prices and real wages in this period suggests that the real appreciation is not due to a resumption of a dominant BSH. Instead it appears to be due to tightening rural labour markets associated with improvements in the agricultural terms of trade, combined with slowing overall labour force growth.

While much attention is paid in the literature to the 'undervaluation' of the RMB, it is incorrect to blame this on China's monetary policy, narrowly defined, to include the 
exchange rate target and the accumulation of foreign exchange reserves. The key constraints are capital controls, motivated by concern about financial (and exchange rate) stability in the face of the relative immaturity of its commercial banking sector, and structurally determined high savings. While ever these remain and the currency is non-convertible, reserves will accumulate and exchange rate adjustment will not address the current account imbalance.

In the long term, whether there is a sustained upward trend in China's real exchange rate will depend on the relative strengths of appreciating forces, including tradable productivity growth, reduced savings and labour force decline, and depreciating forces that include productivity growth in its services sector. In the context of China's current transition toward inwardly-generated growth, these have tended to cause a net appreciating trend. This notwithstanding, in the near term the short run effects of financial flows will be dominant and these depend on the direction of the flows (He et al. 2012, Bayoumi and Ohnsorge 2014). Some temporary changes are likely to cause a period of real Chinese depreciation. These include the unwinding of US unconventional monetary policy, which will attract flows from the periphery back into US assets, and the "internationalisation” of the RMB, which is likely to see some outflows as relaxing capital controls allow Chinese residents to diversify private portfolios into foreign assets. 


\section{References}

Aloy, M. and K. Gente, 2009. "The role of demography in the long run Yen-USD real exchange rate appreciation," Journal of Macroeconomics, 31: 654-67.

Anderson, K. ed. 2009. Distortions to Agricultural Incentives: A Global Perspective, 19552007. London: Palgrave Macmillan.

Asea, P.K. and E. G. Mendoza, 1994. 'The Balassa-Samuelson model: a general-equilibrium appraisal', Review of International Economics, 2(3): 244-67.

Bacchetta, P., K. Benhima and Y. Kalantsis, 2014. “Optimal exchange rate policy in a growing semi-open economy”, Hong Kong Institute for Monetary Research Working Paper No.09-2014, May.

Balassa, B 1964. "The purchasing-power parity doctrine: a reappraisal." The Journal of Political Economy, 72(6): 584-96.

Bayoumi, T. and F. Ohnsorge, 2013. "Do inflows or outflows dominate? Global implications of capital account liberalization in China", Working Paper 13/189, International Monetary Fund, Washington DC.

Bayoumi, T., H. Tong and Shang-Jin Wei, 2013. "The Chinese corporate savings puzzle: a firm-level cross-country perspective," in J.P.H. Fan and R. Morck, Capitalizing China. University of Chicago Press: 283 - 308.

Bergin, P.R., R. Glick and A.M. Taylor, 2006. 'Productivity, tradability and the long run price puzzle’, Journal of Monetary Economics, 53(8): 41-66.

Bergin, P. R. and R. Glick, 2009. 'Endogenous tradability and some macroeconomic implications', Journal of Monetary Economics, 56: 1086-95.

Bergsten, C.F. 2010. "Correcting the Chinese exchange rate," Testimony before the Hearing on China's Exchange Rate Policy, Committee on Ways and Means, US House of Representatives; Peterson Institute for International Economics, Washington DC.

Berka, M. and M.B. Devereux, 2010. "What determines European real exchange rates?" NBER Working Paper No. 15753, Cambridge MA.

Betts, C.M. and T.J. Kehoe. 2008. "Real exchange rate movements and the relative price of non-traded goods," NBER Working Paper No. 14437, Cambridge MA.

Bjoernland, H.C. 2008. "Monetary policy and exchange rate interactions in a small open economy," The Scandinavian Journal of Economics, 110(1): 197-221.

Boltho, A. and M. Weber, 2009. "Did China follow the East Asian development model?" The European Journal of Comparative Economics, 6(2): 267-86.

Broeck, M.D. and T. Slok, 2006. "Interpreting real exchange rate movement in transition countries," Journal of International Economics, 68: 368-83.

Cai, F. and D. Wang, 2005. "Demographic transition: implications for growth," in R. Garnaut and L. Song, The China Boom and Its Discontents, Canberra: Asia Pacific Press.

Cai, F. and D. Wang, 2006. "Employment growth, labour scarcity and the nature of China's trade expansion," in R. Garnaut and L. Song, The Turning Point in China's Economic Development, Canberra: Asia Pacific Press.

Chamon, M.D. and E.S. Prasad. 2010. "Why are saving rates of urban households in China rising?" American Economic Journal: Macroeconomics, 2(1): 93-130. 
Chang, J. and R. Tyers, 2008. "Trade reform, macroeconomic policy and sectoral labour movement in China”, Chapter 9 in C. Chen and R. Duncan (eds.), The Impact of WTO Accession and Regional Trade Arrangements on China's Agricultural Sector and Food Security, Canberra: Asia Pacific Press, February: 268-304. Originally published as Chapter 14 in Garnaut, R. and L. Song (eds.) China 2003: New Engine for Growth, Asia Pacific Press, September 2003: 231-275.

Cheung, Yin-Wong, M.D. Chinn and E. Fujii, 2010. "China's current account and exchange rate," In R. C. Feenstra and S.J. Wei, China's Growing Role in World Trade. University of Chicago Press: 231 - 71.

Cheung, Yin-Wong, M. D. Chinn and E. Fujii, 2007. "The overvaluation of renminbi undervaluation." Journal of International Money and Finance, 26: 762-85.

Chinn, M. and H. Ito, 2007. "Current account balances, financial development and institutions: assaying the world 'saving glut'." Journal of International Money and Finance, 26: 546-69.

Chinn, M. and H. Ito, 2008. "Global current account imbalances: American fiscal policy versus East Asian savings." Review of International Economics, 16(3): 479-98.

Chinn, M. D., B. Eichengreen and H. Ito. 2014. "A forensic analysis of global imbalances," Oxford Economic Papers, 66: 465-90.

Chinn, M.Z., 1999. "Productivity, government spending and the real exchange rate: evidence for OECD countries," in R. MacDonald and J. Stein, Equilibrium Exchange Rates. Springer: 163-90.

Chong, Y., O. Jorda and A.M. Taylor, 2010. “The Harrod-Balassa-Samuelson effect: the long run real exchange rate”, NBER Working Paper No. 15868, Cambridge MA.

Combes, Jean-Louis, T. Kinda and P. Plane, 2012. "Capital flows, exchange rate flexibility, and the real exchange rate," Journal of Macroeconomics, 34: 1034-43.

Corsetti, G., L. Dedola and S. Leduc, 2008. "International risk sharing and the transmission of productivity shocks," Review of Economic Studies, 75: 443-73.

Coudert, V. and Couharde, C., 2007. "Real equilibrium exchange rate in China: is the renminbi undervalued?" Journal of Asian Economics, 18(4): 568-94.

Crucini, M.J., C.I. Telmer and M. Zachariadis, 2005. "Understanding European real exchange rates," American Economic Review, 95(3): 724-38.

De Gregorio, J. and H. C. Wolf, 1994. "Terms of trade, productivity, and the real exchange rate”, NBER Working Paper No. 4807, Cambridge MA.

Dimaranan, B.V. and R.A. McDougall, 2002. "Global trade, assistance and production: the GTAP 7 Database," West Lafayette: Center for Global Trade Analysis, Purdue University.

Dornbush, R., 1976. 'The theory of flexible exchange rate regimes and macroeconomic policy.’ The Scandinavian Journal of Economics, 78(2): 255-75.

Drine, I. and C. Rault. 2005. "Can the Balassa-Samuelson theory explain long run real exchange rate movements in OECD countries?" Applied Financial Economics, 15(8): 519-30. 
Dumrongrittikul, T., 2012. "Real exchange rate movements in developed and developing economies: a reinterpretation of the Balassa-Samuelson hypothesis", The Economic Record, 88, 537-553.

Dumrongrittikul, T. and H. M. Anderson, 2013. "Do policy related shocks affect real exchange rates of Asian developing countries?” Econometrics and Business Statistics Working Paper 12/13, Monash University (http://www.buseco.monash.edu.au/ebs/pubs/wpapers/2013/), presented at an invited session at the ASSA meetings, San Diego, January, and at the Econometric Society Australasian Meetings, Sydney, July.

Dumrongrittikul, T., H.M. Anderson and F. Vahid, 2013. "Modelling real exchange rate movements in a global VAR framework", presented at the Symposium for Econometric Theory and Applications, Seoul, July.

Duncan, R., L. Rees and R. Tyers. 2008. "Revisiting the economic costs of food selfsufficiency in China," in C. Chen and R. Duncan, The Impact of WTO Accession and Regional Trade Arrangements on China's Agricultural Sector and Food Security, Canberra: Asia Pacific Press: 203-28.

Eichenbaum, M. and C.L. Evans, 1995. 'Some empirical evidence on the effects of shocks to monetary policy on exchange rates', The Quarterly Journal of Economics, 110(4): 975-1009.

Eichengreen, B., 2008. "The real exchange rate and economic growth," World Bank, Washington DC.

Enders, Z., G.J. Müller and A. Scholl, 2011. 'How do fiscal and technology shocks affect real exchange rates? New evidence for the United States', Journal of International Economics, 83(1): 53-69.

Engel, C., 1999. 'Accounting for U.S. real exchange rate changes', Journal of Political Economy, 107(3): 507-38.

Engel, C. and J.H. Rogers, 1996. 'How wide is the border?' The American Economic Review, 86(5): 1112-25.

Faust, J. and J.H. Rogers, 2003. 'Monetary policy's role in exchange rate behaviour', Journal of Monetary Economics, 50(7): 1403-24.

Feenstra, R.C. and C. Hong. 2010. "China's exports and employment," in R. C. Feenstra and S.-J. Wei, China's Growing Role in World Trade. University of Chicago Press: 16799.

Fleming, J.M., 1962. 'Domestic financial policies under fixed and floating exchange rates', IMF Staff Papers, 9: 369-79.

Fogel, R.W. 2006. "Why China is likely to achieve its growth objectives." NBER Working Paper No.12122, Cambridge MA.

Frankel, J.A., 1981. 'The collapse of purchasing power parity during the 1970s', European Economic Review, 16(1): 145-65.

Frankel, J.A., 1986. 'International capital mobility and crowding-out in the U.S. economy: imperfect integration of financial markets or of goods markets?’, in R. W. Hafer (ed.), How Open Is the U.S. Economy? Lexington MA: Lexington Books, 33-67. 
Frankel, J., 2004. "On the renminbi: the choice between adjustment under a fixed exchange rate and adjustment under a flexible rate," NBER Working Paper No. 11274. Cambridge MA.

Frankel, J.A. and A.K. Rose, 1996. 'A panel project on purchasing power parity: mean reversion within and between Countries', Journal of International Economics, 40(1): 209-24.

Froot, K.A. and F. Rogoff, 1991. Government Consumption and the Real Exchange Rate: The Empirical Evidence, Harvard University.

Froot, K.A. and K. Rogoff, 1995. 'Perspectives on PPP and long-run real exchange rates', in G. Grossman and K. Rogoff (eds.), Handbook of International Economics. Amsterdam: North-Hollan:d 1647-88.

Galstyan, V. and P.R. Lane, 2009. "The composition of government spending and the real exchange rate," Journal of Money, Credit and Banking, 41(6): 1233-49.

Gardner, B., 2010. "China’s labour situation is changing, not for the worse," Roubini Global Economics - Asia Economonitor, 1 June.

Garnaut, R. and Y. Huang, 2007. "Mature Chinese growth leads the global platinum age." R. Garnaut and L. Song, China: Linking Markets for Growth, Canberra: Asia Pacific Press.

Ghironi, F. and M.J. Melitz. 2005. "International trade and macroeconomic dynamics with heterogeneous firms," Quarterly Journal of Economics, 120(3): 865-915.

Goldstein, M., 2004. "Adjusting China's exchange rate policies", Working Paper WP04-1, Peterson Institute for International Economics, Washington DC.

Golley, J. and R. Tyers, 2006. "China's growth to 2030: demographic change and the labour supply constraint," in R. Garnaut and L. Song (eds.), The Turning Point in China's Economic Development. Canberra: Asia Pacific Press.

Golley, J. and R. Tyers, 2007. "China’s real exchange rate," R. Garnaut and L. Song (eds.), China: Linking Markets for Growth. Canberra: Asia Pacific Press.

Gordon, R.J., 2003. "Exploding productivity growth: context, causes, and implications." Brookings Papers on Economic Activity, 2: 207-97.

Halpern, L. and C. Wyplosz, 1997. "Equilibrium exchange rates in transition economies," IMF Staff Papers, 44(4): 430-61.

Harris, R.G. and D. Cox, 1984. "Trade, industrial policy, and Canadian manufacturing," The Canadian Journal of Economics, 17(2): 386-98.

He, D., L. Cheung, W. Zhang and T. Wu, 2012. "How would capital account liberalization affect China's capital flows and the renminbi real exchange rate," China and the World Economy, 20(6): 29-54.

Henning, C.R., 2008. Accountability and Oversight of U.S. Exchange Rate Policy. Washington DC: Peterson Institute for International Economics.

Horioka, C.Y. and A. Terada-Hagiwara, 2012. "The determinants and long term projections of saving rates in developing Asia," Japan and the World Economy, 24, 128-37.

Horioka, C.Y. and J. Wan, 2007. "The determinants of household saving in China: a dynamic panel analysis of provincial data," Journal of Money, Credit and Banking, 39(8): 2077-96. 
Huang, J.S., W. Martin, S. Rozelle and Y. Liu, 2009. "China," in K. Anderson (ed.), Distortions to Agricultural Incentives: A Global Perspective, 1955-2007. London: Palgrave Macmillan.

Huang, Y., J. Chang and L. Yang, 2013. "Consumption recovery and economic rebalancing in China", Asian Economic Papers, 12(1): 47-67.

Ianchovichina, E.I. and T.L. Walmsley (eds.) 2012. Dynamic Modeling and Applications for Global Economic Analysis, New York: Cambridge University Press.

Ito, H., 2009. "U.S. current account debate with Japan then with China now", Journal of Asian Economics, 20: 294-313.

Ito, T., P. Isard and S. Symansky, 1999. "Economic growth and real exchange rate: an overview of the Balassa-Samuelson Hypothesis in Asia," in T. Ito and A. O. Krueger, (eds), Changes in Exchange Rates in Rapidly Development Countries: Theory, Practice, and Policy Issues, University of Chicago Press: 109 - 32.

Kessler, M. and A. Subramanian, 2014. "Is the renminbi still undervalued? Not according to new PPP estimates”, Real Time Economic Issues Watch, Peterson Institute, Washington DC, 1 May.

Kim, S. and N. Roubini, 2008. "Twin deficit or twin divergence? Fiscal policy, the current account and real exchange rate in the U.S.", Journal of International Economics, 74(2): 362-83.

Krugman, P.R., 1987. "Pricing to market when the exchange rate changes," in S. W. Arndt and J. D. Richardson (eds.), Real-Financing Linkages among Open Economies, Cambridge.

Lardy, N. 2006. "China’s interaction with the global economy," R. Garnaut and L. Song, The Turning Point in China’s Economic Development, Canberra: Asia Pacific Press.

Liu, J., N.V. Leeuwen, T., T. Vo, R. Tyers and T.W. Hertel, 1998. "Disaggregating labour payments by skill level in GTAP," Technical Paper, No. 11. Centre for Global Trade Analysis, Purdue University.

Lothian, J. and M. Taylor, 1996. "Real exchange rate behaviour: recent float from the perspective of the past two centuries", Journal of Political Economy, 104(3): 488-509.

Lothian, J. and M. Taylor, 2008. "Real exchange rate over the past two centuries: how important is the Harrod-Balassa-Samuelson effect?" Economic Journal, 118: 1742-63.

Ma, G. and W. Yi, 2010. "China’s high saving rate: myth and reality", International Economics, 122: 5-40.

Ma, Y., 2006. "A comparative study of the competitiveness of the domestic and foreigninvested service industries in China," Centre for Public Policy Studies Working Paper No. 176, Lingnan University, Hong Kong.

Macdonald, R., 1996. "Panel unit root tests and real exchange rate", Economics Letters, 50: 7-11.

McKinnon, R.I., 2006. "China’s Exchange Rate Appreciation in the Light of the Earlier Japanese Experience." Pacific Economic Review, 11(3): 287-98.

McKinnon, R.I., 2014. “China’s currency conundrum”, Economonitor, 28 April. 
Meng, X. and N. Bai, 2007. "How much have the wages of unskilled workers in China increased? Data from seven factories in Guangdong," in R. Garnaut and L. Song (eds.), China: Linking Market for Growth. Canberra: Asia Pacific Press.

Miyajima, K., 2005. "Real exchange rates in growingeEconomies: how strong is the role of the non-tradables sector," IMF Working Papers 05/233, Washington DC.

Modigliani, F. and S. Cao, 2004. "The Chinese saving puzzle and the lifecycle hypothesis." Journal of Economic Literature, 42(1): 145-70.

Monacelli, T. and R. Perotti, 2006. "Fiscal policy, the trade balance and the real exchange rate: implications for international risk sharing," Working Paper, Innocenzo Gasparini Institute for Economic Research (IGIER), Universita Bocconi.

Monacelli, T. and R. Perotti. 2010. "Fiscal policy, the real exchange rate and traded goods." The Economic Journal, 120(544): 437-61.

Mundell, R.A., 1963. "Capital mobility and stabilization policy under fixed and flexible exchange rates," The Canadian Journal of Economics and Political Science, 29(4): 475-85.

Mussa, M. 1986. "Nominal exchange rate regimes and the behavior of real exchange rates; evidence and implications," in K. Brunner and A. H. Meltzer, Real Business Cycles, Real Exchange Rates and Actual Policies, Carnegie Rochester Conference Series on Public Policy 25. Amsterdam: North Holland, 117-214.

National Bureau of Statistics of China. 2013. China Statistical Yearbook 2013, Beijing: China Statistics Press.

O’Mahony, M. and M. P. Timmer. 2009. "Output, input and productivity measures at the industry level: the EU KLEMS Database." Economic Journal, 119(538): 374-403.

Obstfeld, M. and K. Rogoff, 1995. "Exchange Rate Dynamics Redux." Journal of Political Economy, 103: 624-60.

Obstfeld, M. and K. Rogoff, 2000. "New Directions for Stochastic Open Economy Models." Journal of International Economics, 50, 117-53.

Park, J. Y. and M. Shintani, 2005. "Testing for a unit root against transitional autoregressive models”, Working Paper No. 05-W10, Nashiville: Vanderbilt University.

Ravn, M., S. Schmitt-Grohé and M. Uribe, 2006. "Deep habits," Review of Economic Studies, 73(1): 195-218.

Ravn, M., S. Schmitt-Grohé and M. Uribe, 2012. "Explaining the effects of government spending shocks on consumption and the real exchange rate," Journal of Monetary Economics, 59(3): 215-34.

Rees, L. and R. Tyers, 2008. "Trade reform in the short run: China's WTO accession”, Chapter 8 in C. Chen and R. Duncan (eds.), The Impact of WTO Accession and Regional Trade Arrangements on China's Agricultural Sector and Food Security, Canberra: Asia Pacific Press, October; originally published in the Journal of Asian Economics 15(1): 1-31, January-February, 2004.

Ricci, L., G.M. Milesi-Ferretti and J. Lee, 2008. "Real exchange rates and fundamentals: a cross-country perspective," Working Paper No. 08/13. International Monetary Fund.

Rogoff, R., 1996. "The Purchasing Power Parity Puzzle." Journal of Economic Literature, 34(2), 647-68. 
Rose, A.K., S. Supaat and J. Braude, 2009. 'Fertility and the real exchange rate', The Canadian Journal of Economics, 42(2): 496-518.

Samuelson, P., 1964. "Theoretical notes on trade problems," Review of Economics and Statistics, 46(2): 145-54.

Stockman, A.C., 1980. "A theory of exchange rate determination," The Journal of Political Economy, 88(4): 673-98.

Taylor, A.M., 2002. 'A century of purchasing power parity', The Review of Economics and Statistics, 84(1): 139-50.

Taylor, A. M., 2001. 'Potential pitfalls for the purchasing-power-parity puzzle? Sampling and specification biases in mean-reversion tests of the law of one price', Econometrica, 69(2): 473-98.

Taylor, A.M. and M. P. Taylor, 2004. 'The purchasing power parity debate’, The Journal of Economic Perspectives, 18(4): 135-58.

Taylor, M.P., 1995. 'The economics of exchange rates', Journal of Economic Literature, 33(1): 13-47.

Taylor, M.P., D.A. Peel and L. Sarno, 2001. 'Nonlinear mean-reversion in real exchange rates: toward a solution to the purchasing power parity puzzle', International Economic Review, 42(4): 1015-42.

Tyers, R., 2014. “Looking inward for transformative growth”, China Economic Review, forthcoming.

Tyers, R. and I. Bain, 2006. "The global economic implications of freer skilled migration," Working Papers in Economics and Econometrics No.468. Canberra: Australian National University.

Tyers, R., and J. Golley, 2008. “China’s Real Exchange Rate Puzzle”, Journal of Economic Integration, 23: 547-74.

Tyers, R., J. Golley; Y. Bu and I. Bain, 2008. "China's economic growth and its real exchange rate," China Economic Journal, 1(2): 123 - 45.

Tyers, R. and F. Lu, 2009. "Competition policy, corporate saving and China's current account surplus," Working Papers in Economics and Econometrics 496. College of Business and Economics, Australian National University.

Tyers, R. and Q. Shi, 2007. "Global demographic change, policy responses and their economic implications," The World Economy 30(4): 537-66.

2012. "Global demographic change, labour force growth and economic performance", Chapter 13 in Ianchovichina, E. and T. Walmsley, Dynamic Modeling and Applications in Global Economic Analysis, Cambridge University Press: 342-375.

Tyers, R. and Y. Zhang, 2010. "The real exchange rate and the renminbi," in R. Garnaut, J. Golley and L. Song (eds.), China: The Next 20 Years of Reform and Development, Canberra: ANU E Press and Brookings Institution Press, 163-92. , 2011. “Appreciating the renminbi”, The World Economy, 34(2): 265-297, February. , 2014. "Short run implications of China’s reform agenda”, Chapter 5 in R. Garnaut, C. Fang and L. Song (eds), Deepening Reform for China's Long-Term Growth and Development, Canberra: ANU E Press and Beijing: Social Sciences Academic Press. 
Tyers, R., Y. Zhang and T.S. Cheong, 2013. “China’s saving and global economic performance”, Chapter 6 in Garnaut, R., F. Cai and L. Song (eds.), China: A New Model for Growth and Development, Canberra: ANU E Press and Beijing: Social Sciences Academic Press: 97-124.

Wang, T., 2004. "Exchange rate dynamics," in E. Prasad (ed), China's Growth and Integration into the World Economy: Prospects and Challenges. Washington, DC: International Monetary Fund.

Wei, S.J. and X. Zhang, 2011. "The competitive saving motive: evidence from rising sex ratios and saving rates in China," Journal of Political Economy, 199(3): 511-64.

Wen, J., 2008. Report on the Work of the Government. Beijing.

WTO, 2008. "Trade policy review: China,." WT/TPR/G/199, World Trade Organisation, Geneva.

Wu, Yangru., 1996. 'Are real exchange rates non-stationary? Evidence from a panel-data test', Journal of Money, Credit and Banking, 28(1): 54-63.

Wu, Yanrui., 2011. "Total factor productivity growth in China: a review," Journal of Chinese Economic and Business Studies, 9(2): 111-126.

Xiao, G. 2006. "What is special about China's exchange rate and external imbalance: a structural and institutional perspective," Asian Economic Panel 2007, Beijing and Washington DC: Brookings-Tsinghua Center and Brookings Institution.

Yang, D.T., J. Zhang and S. Zhou, 2013. 'Why are saving rates so high in China?' in J.P.H. Fan and R. Morck (eds.), Capitalizing China, University of Chicago Press: 249 - 78.

Yang, D. T., 2012. "Aggregate savings and external imbalances in China." Journal of Economic Perspectives, 26(4): 125-46.

Zhou, S., 2012. "Is the stationarity of the yen real exchange rate a puzzle?” Working Paper 005ECO-106-2012, San Antonio: The University of Texas at San Antonio, College of Business.

Zhou, S. and A.M. Kutan, 2011. 'Is the evidence for PPP reliable? a sustainability examination of the stationarity of real exchange rates', Journal of Banking \& Finance, 35(9): 2479-90. 
Table 1: Definitions of Absolute and Relative PPP

Definitions

Equivalents

Absolute PPP

$E \cdot P=P^{*}$

$e=1$

Relative PPP

$\ln (e)=\ln E+\left(\ln P-\ln P^{*}\right)=0$

$e=e^{*}$

Table 2: Estimated Chinese Total Factor Productivity Growth by Sector

\begin{tabular}{lllll}
\hline \% per year & $\begin{array}{l}\text { Whole } \\
\text { economy }\end{array}$ & Food & Industry & Services \\
\hline $1986-1989$ & 3.5 & 1.4 & 3.8 & 3.8 \\
$1990-1994$ & 5.0 & 1.6 & 7.7 & 2.3 \\
$1995-1997$ & 5.7 & 5.5 & 3.7 & 3.2 \\
$1998-2001$ & 4.1 & -0.2 & 8.9 & -0.5 \\
$2002-2005$ & 6.0 & 5.4 & 6.3 & 4.6 \\
\hline
\end{tabular}

Sources: Analysis of Chinese statistics described in Tyers et al. (2008). Original sources are, for output, China Statistical Year Book (2005), China Industrial Economic Statistical Year Book (every year after 1985) and China Statistical Abstract (2006). Employment data are from China Statistical Year Book (2005), China Industrial Economic Statistical Year Book (every year after 1985) and China Labor Statistical Year Book (every year after 1985). China’s capital stock, in 2000 prices, is taken from Holtz (2006). Sectoral price indices are from China Statistical Abstract (2006). Urban employment is enlarged based on underestimation proportions from Cai and Wang (2006).

\section{Table 3: Contributions to China's Real Exchange Rate Change, 1997-2006}

\begin{tabular}{ll} 
Faster tradable productivity growth - Balassa Samuelson & $+1.6 \%$ \\
Faster skill growth & $-0.6 \%$ \\
WTO accession trade reforms & $-4.2 \%$ \\
Influx on the financial/capital account of North America & $-0.4 \%$ \\
Efflux on the financial/capital account (high saving rate) & $-4.8 \%$ \\
Net effect over 1997-2006 & $\mathbf{- 8 . 1 \%}$ \\
\hline
\end{tabular}

Source: Tyers et al. (2008) comparison of baseline with counterfactual simulations. 


\section{Figure 1: Chinese Sectoral Price Indices, 1990-2013}
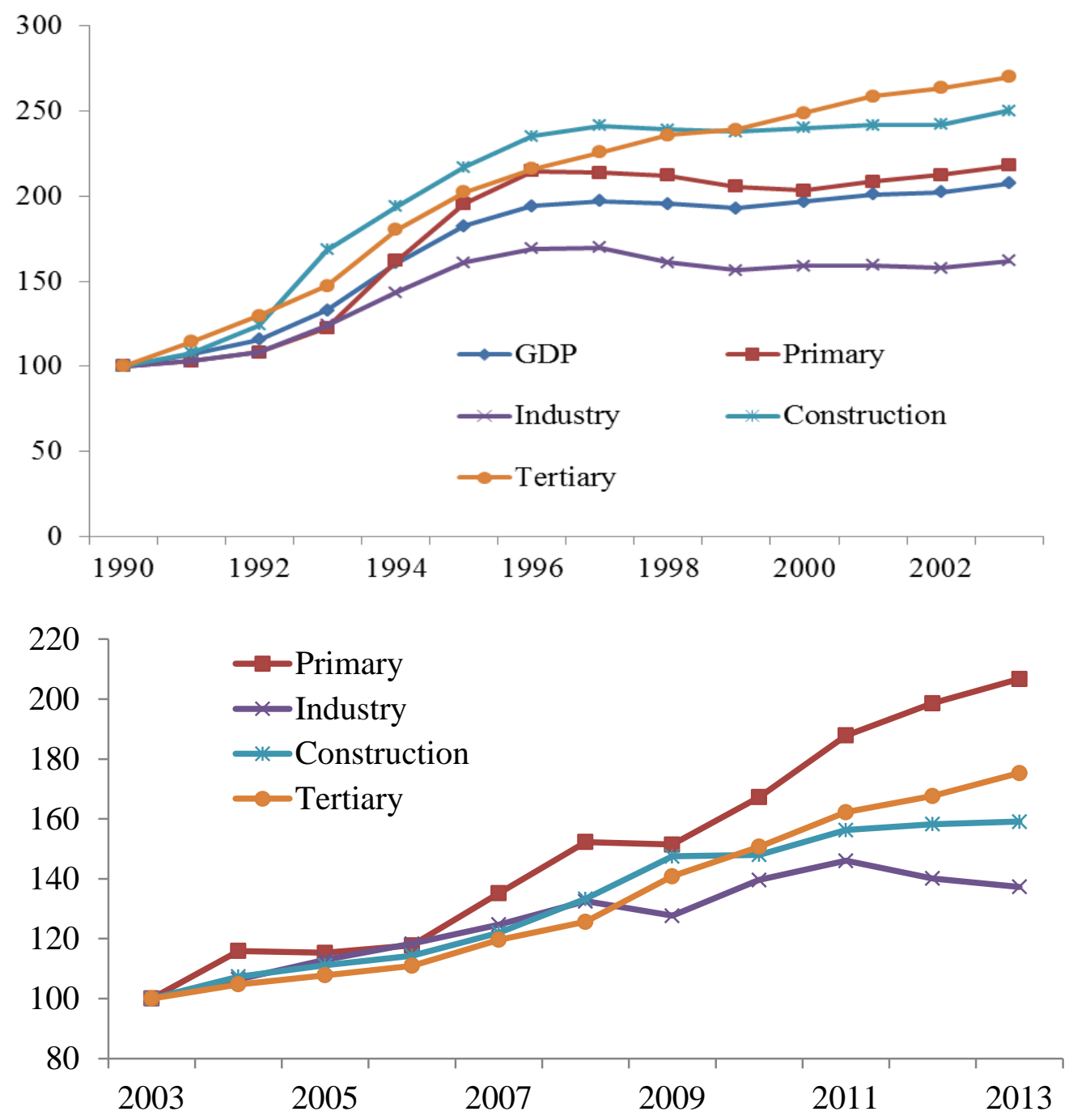

a.These are sectoral price indices for 'Primary industry', which is agriculture and rural services; 'industry', which is primarily manufacturing, and 'construction' (the latter two making up the 'secondary' sector); and 'tertiary industry', which is other services.

Source: Author's calculation based on volume and value data from the National Bureau of Statistics of China (NBSC). 


\section{Figure 2 The Mainland China - US Real Exchange Rate on GDP Prices ${ }^{\mathrm{a}}$}

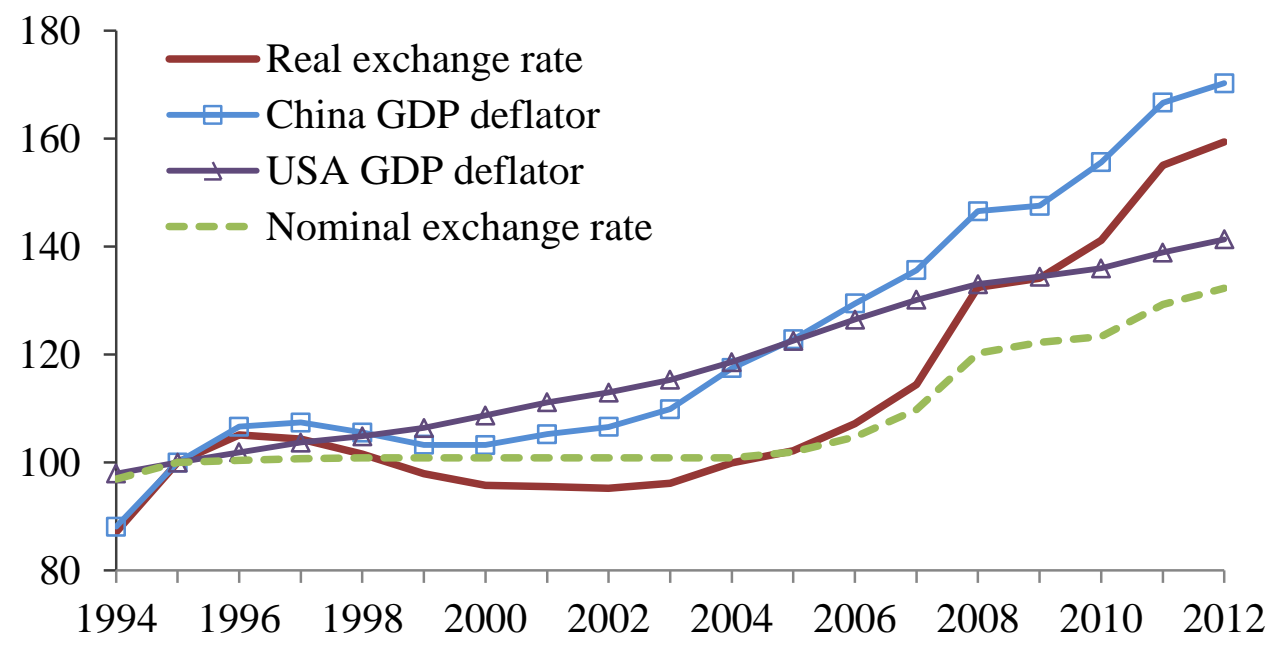

a. These are indices of nominal bilateral rates between mainland China and the US, deflated according to $e_{R}=E \cdot P_{Y} / P_{Y}^{U S}$, where $E$ is the nominal exchange rate in US\$ per unit of local currency, $P_{Y}$ is the local GDP price and $P_{Y}^{U S}$ is the corresponding US GDP price. Source: IMF IFS data base.

\section{Figure 3 China - US Real Exchange Rate on Producer Prices ${ }^{a}$}

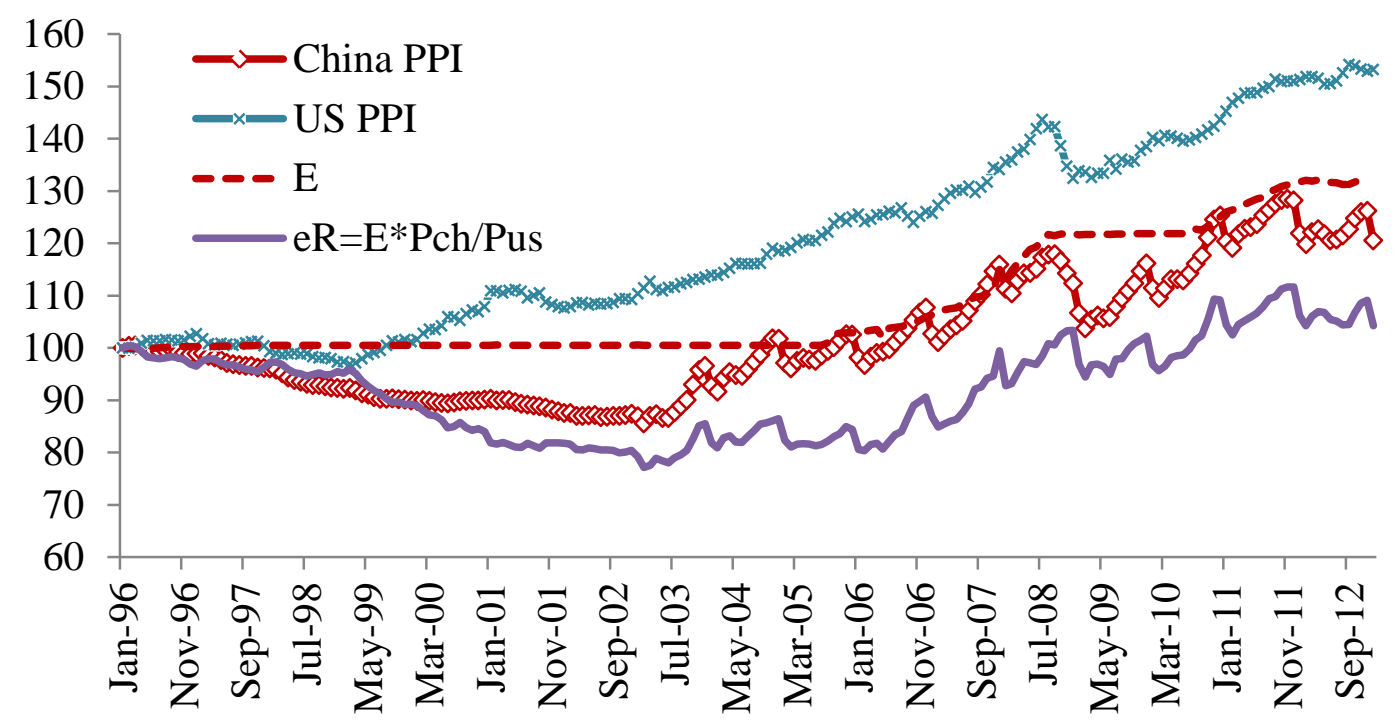

a. Here the home prices are, for the US, the Producer Price Index and, for China, the Corporate Goods Price Index. The Chinese index has more coverage of commodities and services, so this is a less than perfect comparison.

Sources: IMF IFS data base, NBSC, the Bureau of Labor Statistics, USA. 


\section{Figure 4 Elasticities of the Projected Real Exchange Rate to Its Key Determinants $^{\mathrm{a}}$}

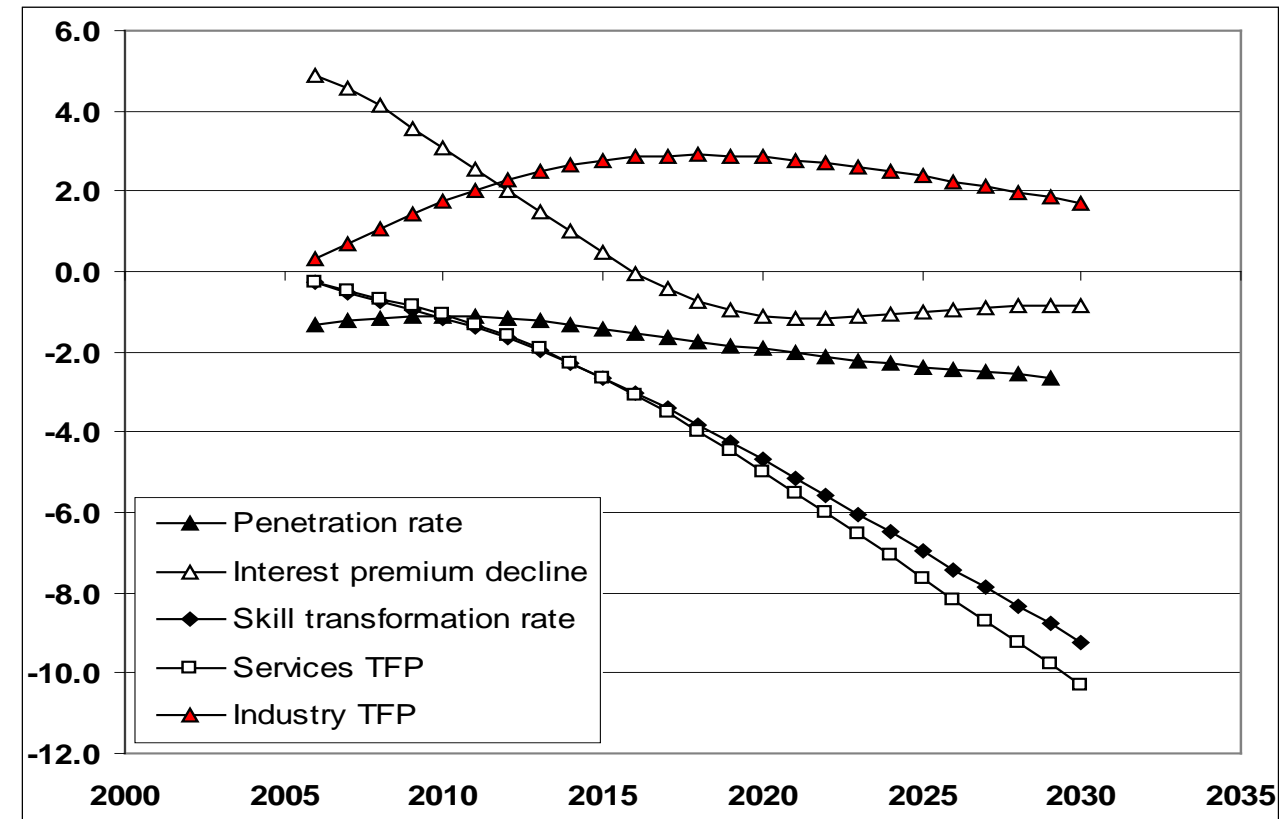

${ }^{a}$ The penetration rate is the percentage departure of the projected real exchange rate for each percentage increase in the overall import penetration ratio, $M / C$, caused by tariff reductions that began in 2005.

Source: Simulations using the model described in Tyers et al (2008).

Figure 5: China's Investment-Saving and External Balances (\% GDP) ${ }^{\text {a }}$

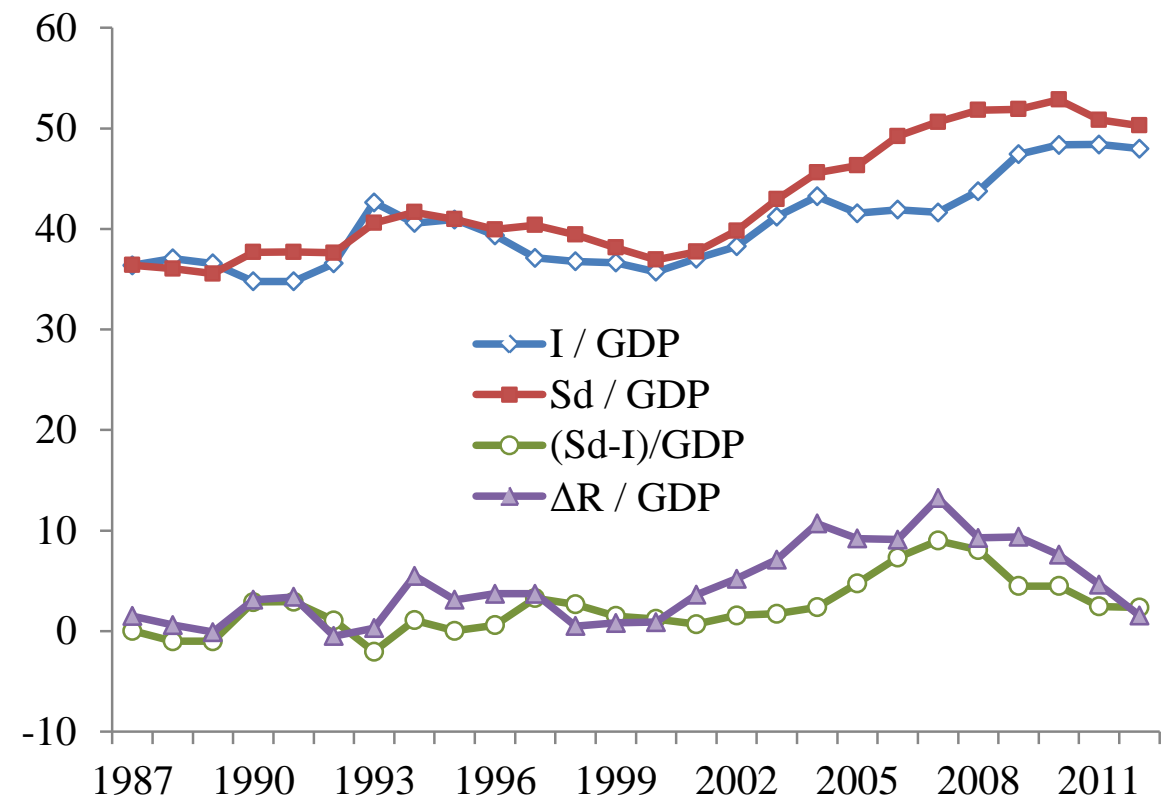

\footnotetext{
${ }^{\text {a }}$ Since errors and omissions are large, we have adjusted the least accurately measured items in each sub-account (usually net factor income and net private flows on the financial account) to ensure balance.
}

Sources: IMF IFS data base. NBSC, China Statistical Yearbook 2013. 
Figure 6: Zivot-Andrews Test for Structural Break in Chinse Real Wages by Sector $^{\mathrm{a}}$
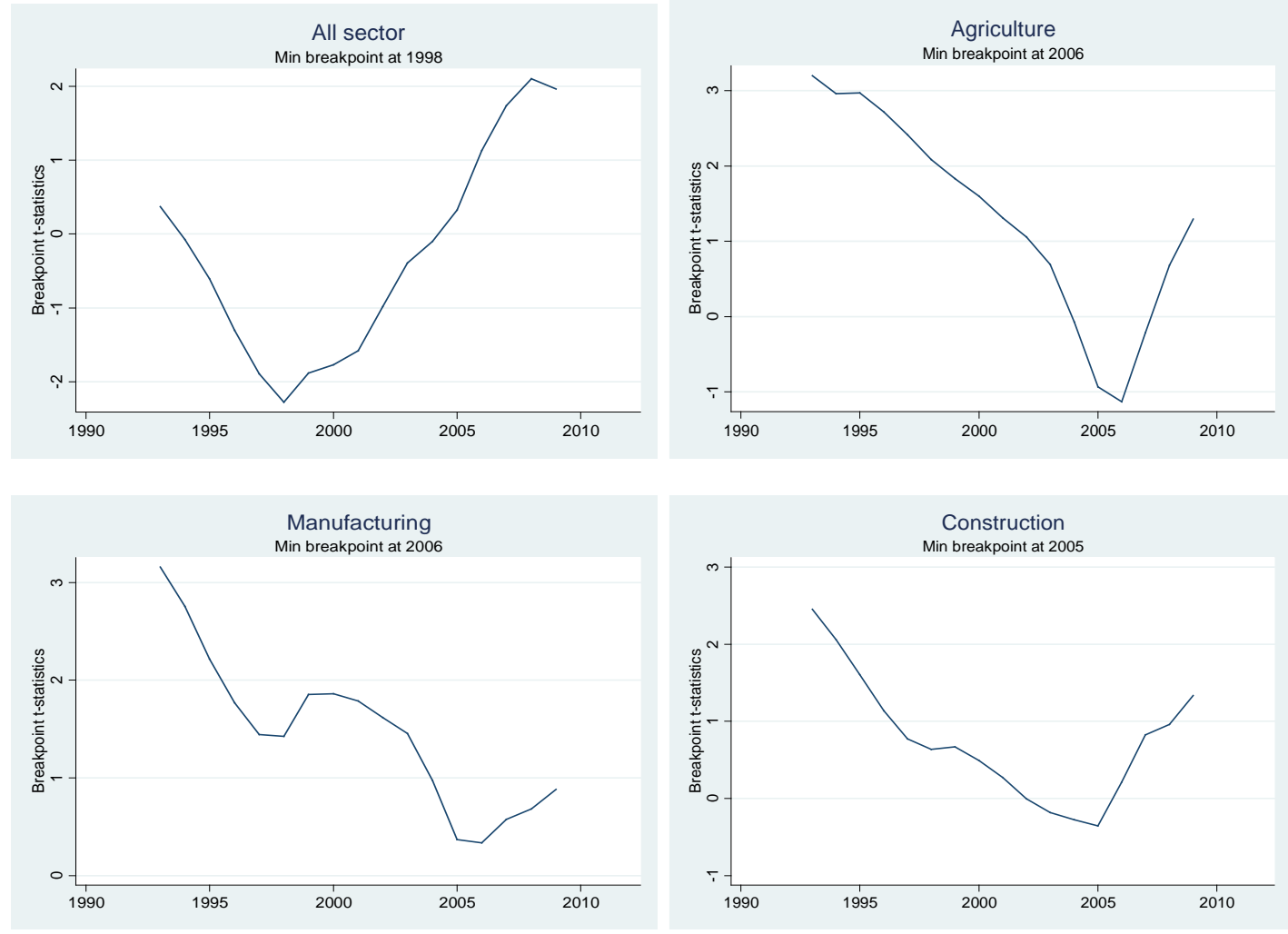

a The real wage is calculated as nominal wage deflated by the CPI. 'All sector' real wage is the weighted average wage across 19 sectors reported by NBSC.

Source: Author's calculation. The nominal wage by sector and the CPI are from NBSC China Statistical Yearbook 2013. 
Editor, UWA Economics Discussion Papers:

Ernst Juerg Weber

Business School - Economics

University of Western Australia

35 Sterling Hwy

Crawley WA 6009

Australia

Email: ecoadmin@biz.uwa.edu.au

The Economics Discussion Papers are available at:

1980 - 2002: http://ecompapers.biz.uwa.edu.au/paper/PDF\%20of\%20Discussion\%20Papers/

Since 2001: http://ideas.repec.org/s/uwa/wpaper1.html

Since 2004: http://www.business.uwa.edu.au/school/disciplines/economics

\begin{tabular}{|c|c|c|}
\hline \multicolumn{3}{|c|}{$\begin{array}{l}\text { ECONOMICS DISCUSSION PAPERS } \\
2012\end{array}$} \\
\hline $\begin{array}{l}\text { DP } \\
\text { NUMBER }\end{array}$ & AUTHORS & TITLE \\
\hline 12.01 & $\begin{array}{l}\text { Clements, K.W., Gao, G., and } \\
\text { Simpson, T. }\end{array}$ & $\begin{array}{l}\text { DISPARITIES IN INCOMES AND PRICES } \\
\text { INTERNATIONALLY }\end{array}$ \\
\hline 12.02 & Tyers, R. & $\begin{array}{l}\text { THE RISE AND ROBUSTNESS OF ECONOMIC FREEDOM } \\
\text { IN CHINA }\end{array}$ \\
\hline 12.03 & Golley, J. and Tyers, R. & $\begin{array}{l}\text { DEMOGRAPHIC DIVIDENDS, DEPENDENCIES AND } \\
\text { ECONOMIC GROWTH IN CHINA AND INDIA }\end{array}$ \\
\hline 12.04 & Tyers, R. & LOOKING INWARD FOR GROWTH \\
\hline 12.05 & Knight, K. and McLure, M. & THE ELUSIVE ARTHUR PIGOU \\
\hline 12.06 & McLure, M. & $\begin{array}{l}\text { ONE HUNDRED YEARS FROM TODAY: A. C. PIGOU'S } \\
\text { WEALTH AND WELFARE }\end{array}$ \\
\hline 12.07 & Khuu, A. and Weber, E.J. & HOW AUSTRALIAN FARMERS DEAL WITH RISK \\
\hline 12.08 & Chen, M. and Clements, K.W. & PATTERNS IN WORLD METALS PRICES \\
\hline 12.09 & Clements, K.W. & UWA ECONOMICS HONOURS \\
\hline 12.10 & Golley, J. and Tyers, R. & $\begin{array}{l}\text { CHINA'S GENDER IMBALANCE AND ITS ECONOMIC } \\
\text { PERFORMANCE }\end{array}$ \\
\hline 12.11 & Weber, E.J. & $\begin{array}{l}\text { AUSTRALIAN FISCAL POLICY IN THE AFTERMATH OF } \\
\text { THE GLOBAL FINANCIAL CRISIS }\end{array}$ \\
\hline 12.12 & Hartley, P.R. and Medlock III, K.B. & $\begin{array}{l}\text { CHANGES IN THE OPERATIONAL EFFICIENCY OF } \\
\text { NATIONAL OIL COMPANIES }\end{array}$ \\
\hline 12.13 & $\mathrm{Li}, \mathrm{L}$. & $\begin{array}{l}\text { HOW MUCH ARE RESOURCE PROJECTS WORTH? A } \\
\text { CAPITAL MARKET PERSPECTIVE }\end{array}$ \\
\hline 12.14 & Chen, A. and Groenewold, N. & $\begin{array}{l}\text { THE REGIONAL ECONOMIC EFFECTS OF A } \\
\text { REDUCTION IN CARBON EMISSIONS AND AN } \\
\text { EVALUATION OF OFFSETTING POLICIES IN CHINA }\end{array}$ \\
\hline 12.15 & Collins, J., Baer, B. and Weber, E.J. & $\begin{array}{l}\text { SEXUAL SELECTION, CONSPICUOUS CONSUMPTION } \\
\text { AND ECONOMIC GROWTH }\end{array}$ \\
\hline
\end{tabular}




\begin{tabular}{|c|c|c|}
\hline \multicolumn{3}{|c|}{$\begin{array}{l}\text { ECONOMICS DISCUSSION PAPERS } \\
2012\end{array}$} \\
\hline $\begin{array}{l}\text { DP } \\
\text { NUMBER }\end{array}$ & AUTHORS & TITLE \\
\hline 12.16 & Wu, Y. & TRENDS AND PROSPECTS IN CHINA'S R\&D SECTOR \\
\hline 12.17 & Cheong, T.S. and Wu, Y. & $\begin{array}{l}\text { INTRA-PROVINCIAL INEQUALITY IN CHINA: AN } \\
\text { ANALYSIS OF COUNTY-LEVEL DATA }\end{array}$ \\
\hline 12.18 & Cheong, T.S. & THE PATTERNS OF REGIONAL INEQUALITY IN CHINA \\
\hline 12.19 & Wu, Y. & $\begin{array}{l}\text { ELECTRICITY MARKET INTEGRATION: GLOBAL } \\
\text { TRENDS AND IMPLICATIONS FOR THE EAS REGION }\end{array}$ \\
\hline 12.20 & Knight, K. & $\begin{array}{l}\text { EXEGESIS OF DIGITAL TEXT FROM THE HISTORY OF } \\
\text { ECONOMIC THOUGHT: A COMPARATIVE } \\
\text { EXPLORATORY TEST }\end{array}$ \\
\hline 12.21 & Chatterjee, I. & $\begin{array}{l}\text { COSTLY REPORTING, EX-POST MONITORING, AND } \\
\text { COMMERCIAL PIRACY: A GAME THEORETIC } \\
\text { ANALYSIS }\end{array}$ \\
\hline 12.22 & Pen, S.E. & QUALITY-CONSTANT ILLICIT DRUG PRICES \\
\hline 12.23 & Cheong, T.S. and Wu, Y. & $\begin{array}{l}\text { REGIONAL DISPARITY, TRANSITIONAL DYNAMICS } \\
\text { AND CONVERGENCE IN CHINA }\end{array}$ \\
\hline 12.24 & Ezzati, P. & $\begin{array}{l}\text { FINANCIAL MARKETS INTEGRATION OF IRAN } \\
\text { WITHIN THE MIDDLE EAST AND WITH THE REST OF } \\
\text { THE WORLD }\end{array}$ \\
\hline 12.25 & Kwan, F., Wu, Y. and Zhuo, S. & $\begin{array}{l}\text { RE-EXAMINATION OF THE SURPLUS AGRICULTURAL } \\
\text { LABOUR IN CHINA }\end{array}$ \\
\hline 12.26 & Wu, Y. & R\&D BEHAVIOUR IN CHINESE FIRMS \\
\hline 12.27 & Tang, S.H.K. and Yung, L.C.W. & $\begin{array}{l}\text { MAIDS OR MENTORS? THE EFFECTS OF LIVE-IN } \\
\text { FOREIGN DOMESTIC WORKERS ON SCHOOL } \\
\text { CHILDREN'S EDUCATIONAL ACHIEVEMENT IN HONG } \\
\text { KONG }\end{array}$ \\
\hline 12.28 & Groenewold, N. & $\begin{array}{l}\text { AUSTRALIA AND THE GFC: SAVED BY ASTUTE } \\
\text { FISCAL POLICY? }\end{array}$ \\
\hline
\end{tabular}




\begin{tabular}{|c|c|c|}
\hline \multicolumn{3}{|c|}{$\begin{array}{l}\text { ECONOMICS DISCUSSION PAPERS } \\
2013\end{array}$} \\
\hline $\begin{array}{l}\text { DP } \\
\text { NUMBER }\end{array}$ & AUTHORS & TITLE \\
\hline 13.01 & $\begin{array}{l}\text { Chen, M., Clements, K.W. and } \\
\text { Gao, G. }\end{array}$ & THREE FACTS ABOUT WORLD METAL PRICES \\
\hline 13.02 & Collins, J. and Richards, O. & $\begin{array}{l}\text { EVOLUTION, FERTILITY AND THE AGEING } \\
\text { POPULATION }\end{array}$ \\
\hline 13.03 & $\begin{array}{l}\text { Clements, K., Genberg, H., } \\
\text { Harberger, A., Lothian, J., } \\
\text { Mundell, R., Sonnenschein, H. and } \\
\text { Tolley, G. }\end{array}$ & LARRY SJAASTAD, 1934-2012 \\
\hline 13.04 & Robitaille, M.C. and Chatterjee, I. & MOTHERS-IN-LAW AND SON PREFERENCE IN INDIA \\
\hline 13.05 & Clements, K.W. and Izan, I.H.Y. & $\begin{array}{l}\text { REPORT ON THE } 25^{\mathrm{TH}} \text { PHD CONFERENCE IN } \\
\text { ECONOMICS AND BUSINESS }\end{array}$ \\
\hline 13.06 & Walker, A. and Tyers, R. & QUANTIFYING AUSTRALIA’S “THREE SPEED” BOOM \\
\hline 13.07 & $\mathrm{Yu}, \mathrm{F}$. and $\mathrm{Wu}, \mathrm{Y}$. & PATENT EXAMINATION AND DISGUISED PROTECTION \\
\hline 13.08 & Yu, F. and Wu, Y. & $\begin{array}{l}\text { PATENT CITATIONS AND KNOWLEDGE SPILLOVERS: } \\
\text { AN ANALYSIS OF CHINESE PATENTS REGISTER IN } \\
\text { THE US }\end{array}$ \\
\hline 13.09 & Chatterjee, I. and Saha, B. & BARGAINING DELEGATION IN MONOPOLY \\
\hline 13.10 & Cheong, T.S. and Wu, Y. & $\begin{array}{l}\text { GLOBALIZATION AND REGIONAL INEQUALITY IN } \\
\text { CHINA }\end{array}$ \\
\hline 13.11 & Cheong, T.S. and $\mathrm{Wu}, \mathrm{Y}$. & INEQUALITY AND CRIME RATES IN CHINA \\
\hline 13.12 & Robertson, P.E. and Ye, L. & ON THE EXISTENCE OF A MIDDLE INCOME TRAP \\
\hline 13.13 & Robertson, P.E. & THE GLOBAL IMPACT OF CHINA’S GROWTH \\
\hline 13.14 & $\begin{array}{l}\text { Hanaki, N., Jacquemet, N., } \\
\text { Luchini, S., and Zylbersztejn, A. }\end{array}$ & $\begin{array}{l}\text { BOUNDED RATIONALITY AND STRATEGIC } \\
\text { UNCERTAINTY IN A SIMPLE DOMINANCE SOLVABLE } \\
\text { GAME }\end{array}$ \\
\hline 13.15 & $\begin{array}{l}\text { Okatch, Z., Siddique, A. and } \\
\text { Rammohan, A. }\end{array}$ & $\begin{array}{l}\text { DETERMINANTS OF INCOME INEQUALITY IN } \\
\text { BOTSWANA }\end{array}$ \\
\hline 13.16 & Clements, K.W. and Gao, G. & $\begin{array}{l}\text { A MULTI-MARKET APPROACH TO MEASURING THE } \\
\text { CYCLE }\end{array}$ \\
\hline 13.17 & Chatterjee, I. and Ray, R. & $\begin{array}{l}\text { THE ROLE OF INSTITUTIONS IN THE INCIDENCE OF } \\
\text { CRIME AND CORRUPTION }\end{array}$ \\
\hline 13.18 & Fu, D. and Wu, Y. & $\begin{array}{l}\text { EXPORT SURVIVAL PATTERN AND DETERMINANTS } \\
\text { OF CHINESE MANUFACTURING FIRMS }\end{array}$ \\
\hline 13.19 & Shi, X., Wu, Y. and Zhao, D. & $\begin{array}{l}\text { KNOWLEDGE INTENSIVE BUSINESS SERVICES AND } \\
\text { THEIR IMPACT ON INNOVATION IN CHINA }\end{array}$ \\
\hline 13.20 & $\begin{array}{l}\text { Tyers, R., Zhang, Y. and } \\
\text { Cheong, T.S. }\end{array}$ & $\begin{array}{l}\text { CHINA'S SAVING AND GLOBAL ECONOMIC } \\
\text { PERFORMANCE }\end{array}$ \\
\hline 13.21 & Collins, J., Baer, B. and Weber, E.J. & $\begin{array}{l}\text { POPULATION, TECHNOLOGICAL PROGRESS AND THE } \\
\text { EVOLUTION OF INNOVATIVE POTENTIAL }\end{array}$ \\
\hline 13.22 & Hartley, P.R. & THE FUTURE OF LONG-TERM LNG CONTRACTS \\
\hline 13.23 & Tyers, R. & $\begin{array}{l}\text { A SIMPLE MODEL TO STUDY GLOBAL } \\
\text { MACROECONOMIC INTERDEPENDENCE }\end{array}$ \\
\hline
\end{tabular}




\begin{tabular}{|c|c|c|}
\hline \multicolumn{3}{|c|}{$\begin{array}{l}\text { ECONOMICS DISCUSSION PAPERS } \\
2013\end{array}$} \\
\hline $\begin{array}{l}\text { DP } \\
\text { NUMBER }\end{array}$ & AUTHORS & TITLE \\
\hline 13.24 & McLure, M. & $\begin{array}{l}\text { REFLECTIONS ON THE QUANTITY THEORY: PIGOU IN } \\
1917 \text { AND PARETO IN 1920-21 }\end{array}$ \\
\hline 13.25 & Chen, A. and Groenewold, N. & $\begin{array}{l}\text { REGIONAL EFFECTS OF AN EMISSIONS-REDUCTION } \\
\text { POLICY IN CHINA: THE IMPORTANCE OF THE } \\
\text { GOVERNMENT FINANCING METHOD }\end{array}$ \\
\hline 13.26 & Siddique, M.A.B. & $\begin{array}{l}\text { TRADE RELATIONS BETWEEN AUSTRALIA AND } \\
\text { THAILAND: } 1990 \text { TO } 2011\end{array}$ \\
\hline 13.27 & Li, B. and Zhang, J. & $\begin{array}{l}\text { GOVERNMENT DEBT IN AN INTERGENERATIONAL } \\
\text { MODEL OF ECONOMIC GROWTH, ENDOGENOUS } \\
\text { FERTILITY, AND ELASTIC LABOR WITH AN } \\
\text { APPLICATION TO JAPAN }\end{array}$ \\
\hline 13.28 & Robitaille, M. and Chatterjee, I. & $\begin{array}{l}\text { SEX-SELECTIVE ABORTIONS AND INFANT } \\
\text { MORTALITY IN INDIA: THE ROLE OF PARENTS’ } \\
\text { STATED SON PREFERENCE }\end{array}$ \\
\hline 13.29 & Ezzati, P. & $\begin{array}{l}\text { ANALYSIS OF VOLATILITY SPILLOVER EFFECTS: } \\
\text { TWO-STAGE PROCEDURE BASED ON A MODIFIED } \\
\text { GARCH-M }\end{array}$ \\
\hline 13.30 & Robertson, P. E. & $\begin{array}{l}\text { DOES A FREE MARKET ECONOMY MAKE AUSTRALIA } \\
\text { MORE OR LESS SECURE IN A GLOBALISED WORLD? }\end{array}$ \\
\hline 13.31 & $\begin{array}{l}\text { Das, S., Ghate, C. and } \\
\text { Robertson, P. E. }\end{array}$ & $\begin{array}{l}\text { REMOTENESS AND UNBALANCED GROWTH: } \\
\text { UNDERSTANDING DIVERGENCE ACROSS INDIAN } \\
\text { DISTRICTS }\end{array}$ \\
\hline 13.32 & Robertson, P.E. and Sin, A. & $\begin{array}{l}\text { MEASURING HARD POWER: CHINA’S ECONOMIC } \\
\text { GROWTH AND MILITARY CAPACITY }\end{array}$ \\
\hline 13.33 & $\mathrm{Wu}, \mathrm{Y}$. & $\begin{array}{l}\text { TRENDS AND PROSPECTS FOR THE RENEWABLE } \\
\text { ENERGY SECTOR IN THE EAS REGION }\end{array}$ \\
\hline 13.34 & $\begin{array}{l}\text { Yang, S., Zhao, D., Wu, Y. and } \\
\text { Fan, J. }\end{array}$ & $\begin{array}{l}\text { REGIONAL VARIATION IN CARBON EMISSION AND } \\
\text { ITS DRIVING FORCES IN CHINA: AN INDEX } \\
\text { DECOMPOSITION ANALYSIS }\end{array}$ \\
\hline
\end{tabular}




\begin{tabular}{|c|c|c|}
\hline \multicolumn{3}{|c|}{$\begin{array}{l}\text { ECONOMICS DISCUSSION PAPERS } \\
\qquad 2014\end{array}$} \\
\hline $\begin{array}{l}\text { DP } \\
\text { NUMBER }\end{array}$ & AUTHORS & TITLE \\
\hline 14.01 & $\begin{array}{l}\text { Boediono, Vice President of the } \\
\text { Republic of Indonesia }\end{array}$ & $\begin{array}{l}\text { THE CHALLENGES OF POLICY MAKING IN A YOUNG } \\
\text { DEMOCRACY: THE CASE OF INDONESIA (52ND } \\
\text { SHANN MEMORIAL LECTURE, 2013) }\end{array}$ \\
\hline 14.02 & Metaxas, P.E. and Weber, E.J. & $\begin{array}{l}\text { AN AUSTRALIAN CONTRIBUTION TO } \\
\text { INTERNATIONAL TRADE THEORY: THE DEPENDENT } \\
\text { ECONOMY MODEL }\end{array}$ \\
\hline 14.03 & Fan, J., Zhao, D., Wu, Y. and Wei, J. & $\begin{array}{l}\text { CARBON PRICING AND ELECTRICITY MARKET } \\
\text { REFORMS IN CHINA }\end{array}$ \\
\hline 14.04 & McLure, M. & $\begin{array}{l}\text { A.C. PIGOU'S MEMBERSHIP OF THE 'CHAMBERLAIN- } \\
\text { BRADBURY' COMMITTEE. } \\
\text { PART I: THE HISTORICAL CONTEXT }\end{array}$ \\
\hline 14.05 & McLure, M. & $\begin{array}{l}\text { A.C. PIGOU’S MEMBERSHIP OF THE ‘CHAMBERLAIN- } \\
\text { BRADBURY’ COMMITTEE. } \\
\text { PART II: ‘TRANSITIONAL’AND ‘ONGOING’ ISSUES }\end{array}$ \\
\hline 14.06 & King, J.E. and McLure, M. & HISTORY OF THE CONCEPT OF VALUE \\
\hline 14.07 & Williams, A. & $\begin{array}{l}\text { A GLOBAL INDEX OF INFORMATION AND POLITICAL } \\
\text { TRANSPARENCY }\end{array}$ \\
\hline 14.08 & Knight, K. & $\begin{array}{l}\text { A.C. PIGOU'S THE THEORY OF UNEMPLOYMENT AND } \\
\text { ITS CORRIGENDA: THE LETTERS OF MAURICE } \\
\text { ALLEN, ARTHUR L. BOWLEY, RICHARD KAHN AND } \\
\text { DENNIS ROBERTSON }\end{array}$ \\
\hline 14.09 & Cheong, T.S. and Wu, Y. & $\begin{array}{l}\text { THE IMPACTS OF STRUCTURAL RANSFORMATION } \\
\text { AND INDUSTRIAL UPGRADING ON REGIONAL } \\
\text { INEQUALITY IN CHINA }\end{array}$ \\
\hline 14.10 & $\begin{array}{l}\text { Chowdhury, M.H., Dewan, M.N.A., } \\
\text { Quaddus, M., Naude, M. and } \\
\text { Siddique, A. }\end{array}$ & $\begin{array}{l}\text { GENDER EQUALITY AND SUSTAINABLE } \\
\text { DEVELOPMENT WITH A FOCUS ON THE COASTAL } \\
\text { FISHING COMMUNITY OF BANGLADESH }\end{array}$ \\
\hline 14.11 & Bon, J. & $\begin{array}{l}\text { UWA DISCUSSION PAPERS IN ECONOMICS: THE FIRST } \\
750\end{array}$ \\
\hline 14.12 & Finlay, K. and Magnusson, L.M. & $\begin{array}{l}\text { BOOTSTRAP METHODS FOR INFERENCE WITH } \\
\text { CLUSTER-SAMPLE IV MODELS }\end{array}$ \\
\hline 14.13 & Chen, A. and Groenewold, N. & $\begin{array}{l}\text { THE EFFECTS OF MACROECONOMIC SHOCKS ON THE } \\
\text { DISTRIBUTION OF PROVINCIAL OUTPUT IN CHINA: } \\
\text { ESTIMATES FROM A RESTRICTED VAR MODEL }\end{array}$ \\
\hline 14.14 & Hartley, P.R. and Medlock III, K.B. & $\begin{array}{l}\text { THE VALLEY OF DEATH FOR NEW ENERGY } \\
\text { TECHNOLOGIES }\end{array}$ \\
\hline 14.15 & $\begin{array}{l}\text { Hartley, P.R., Medlock III, K.B., } \\
\text { Temzelides, T. and Zhang, X. }\end{array}$ & $\begin{array}{l}\text { LOCAL EMPLOYMENT IMPACT FROM COMPETING } \\
\text { ENERGY SOURCES: SHALE GAS VERSUS WIND } \\
\text { GENERATION IN TEXAS }\end{array}$ \\
\hline 14.16 & Tyers, R. and Zhang, Y. & $\begin{array}{l}\text { SHORT RUN EFFECTS OF THE ECONOMIC REFORM } \\
\text { AGENDA }\end{array}$ \\
\hline 14.17 & Clements, K.W., Si, J. and Simpson, T. & UNDERSTANDING NEW RESOURCE PROJECTS \\
\hline 14.18 & Tyers, R. & $\begin{array}{l}\text { SERVICE OLIGOPOLIES AND AUSTRALIA'S } \\
\text { ECONOMY-WIDE PERFORMANCE }\end{array}$ \\
\hline 14.19 & Tyers, R. and Zhang, Y. & $\begin{array}{l}\text { REAL EXCHANGE RATE DETERMINATION AND THE } \\
\text { CHINA PUZZLE }\end{array}$ \\
\hline
\end{tabular}




\begin{tabular}{|c|c|c|}
\hline \multicolumn{3}{|c|}{$\begin{array}{l}\text { ECONOMICS DISCUSSION PAPERS } \\
2014\end{array}$} \\
\hline $\begin{array}{l}\text { DP } \\
\text { NUMBER }\end{array}$ & AUTHORS & TITLE \\
\hline 14.20 & Ingram, S.R. & $\begin{array}{l}\text { COMMODITY PRICE CHANGES ARE CONCENTRATED } \\
\text { AT THE END OF THE CYCLE }\end{array}$ \\
\hline 14.21 & Cheong, T.S. and Wu, Y. & $\begin{array}{l}\text { CHINA'S INDUSTRIAL OUTPUT: A COUNTY-LEVEL } \\
\text { STUDY USING A NEW FRAMEWORK OF } \\
\text { DISTRIBUTION DYNAMICS ANALYSIS }\end{array}$ \\
\hline 14.22 & $\begin{array}{l}\text { Siddique, M.A.B., Wibowo, H. and } \\
\text { Wu, Y. }\end{array}$ & $\begin{array}{l}\text { FISCAL DECENTRALISATION AND INEQUALITY IN } \\
\text { INDONESIA: 1999-2008 }\end{array}$ \\
\hline 14.23 & Tyers, R. & $\begin{array}{l}\text { ASYMMETRY IN BOOM-BUST SHOCKS: AUSTRALIAN } \\
\text { PERFORMANCE WITH OLIGOPOLY }\end{array}$ \\
\hline 14.24 & Arora, V., Tyers, R. and Zhang, Y. & $\begin{array}{l}\text { RECONSTRUCTING THE SAVINGS GLUT: THE } \\
\text { GLOBAL IMPLICATIONS OF ASIAN EXCESS SAVING }\end{array}$ \\
\hline 14.25 & Tyers, R. & $\begin{array}{l}\text { INTERNATIONAL EFFECTS OF CHINA'S RISE AND } \\
\text { TRANSITION: NEOCLASSICAL AND KEYNESIAN } \\
\text { PERSPECTIVES }\end{array}$ \\
\hline 14.26 & Milton, S. and Siddique, M.A.B. & $\begin{array}{l}\text { TRADE CREATION AND DIVERSION UNDER THE } \\
\text { THAILAND-AUSTRALIA FREE TRADE AGREEMENT } \\
\text { (TAFTA) }\end{array}$ \\
\hline 14.27 & Clements, K.W. and Li, L. & VALUING RESOURCE INVESTMENTS \\
\hline
\end{tabular}

